\title{
Collaborative Interferon- $\gamma$ and Interleukin-17 Signaling Protects the Oral Mucosa from Staphylococcus aureus
}

Jobert G. Barin, ${ }^{*}$ Monica V. Talor, ${ }^{*}$ Julie A. Schaub, ${ }^{*}$ Nicola L. Diny, ${ }^{\dagger}$ Xuezhou Hou, ${ }^{\dagger}$ Matthew Hoyer, ${ }^{*}$ Nathan K. Archer, Elizabeth S. Gebremariam, ${ }^{*}$ Meghan F. Davis, ${ }^{\S}$ Lloyd S. Miller, ${ }^{\ddagger}$ Noel R. Rose, ${ }^{* \dagger}$ and Daniela Ciháková ${ }^{* \dagger}$

From the Departments of Pathology* and Dermatology, ${ }^{\ddagger}$ The Johns Hopkins University School of Medicine, Baltimore; and the W. Harry Feinstone Department of Molecular Microbiology \& Immunology ${ }^{\dagger}$ and the Department of Environmental Health Sciences, ${ }^{\S}$ The Johns Hopkins Bloomberg School of Public Health, Baltimore, Maryland

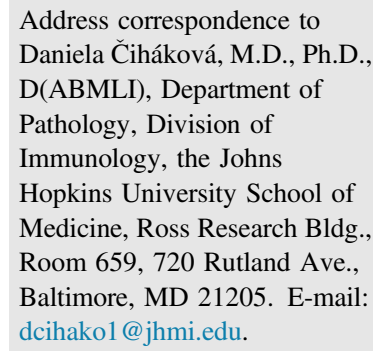

\begin{abstract}
Infections with Staphylococcus aureus are a continuing and growing problem in community and hospital settings. Preclinical animal modeling of $S$. aureus relies on experimental infection, which carries some limitations. We describe here a novel, spontaneous model of oral staphylococcal infection in double knockout mice, deficient in the receptors for IL-17 (IL-17RA) and interferon (IFN)- $\gamma$ (IFN $\gamma$ RI), beginning at 6 to 8 weeks of age. IFN $\gamma \mathrm{RI}^{-/-} \mathrm{IL} 17 \mathrm{RA}^{-/-}$(GRAK0) mice developed progressive oral abscesses. Cytometric methods revealed extensive neutrophilic infiltration of oral tissues in GRAKO mice; further investigation evidenced that IL-17 predominated neutrophil defects in these mice. To investigate the contribution of IFN- $\gamma$ signaling to this native host defense to $S$. aureus, we observed perturbations of monocyte recruitment and macrophage differentiation in the oral tissues of GRAKO mice, and CXCL9/ chemokine ligand receptor (CXCR)3-driven recruitment of T-cell oral tissues and draining lymph nodes. To address the former finding, we depleted macrophages and monocytes in vivo from IL17RA ${ }^{-/-}$mice using liposomes loaded with clodronate. This treatment elicited oral abscesses, recapitulating the phenotype of GRAKO mice. From these findings, we propose novel collaborative functions of IL-17 and IFN- $\gamma$, acting through neutrophils and macrophages, respectively, in native mucocutaneous host defenses to $S$. aureus. (Am J Pathol 2016, 186: 2337-2352; http://dx.doi.org/10.1016/j.ajpath.2016.07.001)
\end{abstract}

The complex interplay between the effector program of Th1 cells, controlled by interferon (IFN)- $\gamma$ signaling, and the Th17 program predominated by IL-17 signaling, remains an active area of investigation. To investigate the relation between IFN- $\gamma$ and IL-17A in our mouse model of autoimmune heart disease, we generated double-knockout mutants lacking both IFN- $\gamma$ and IL-17A and reported that these mice develop a particularly severe, fatal eosinophilic form of autoimmune heart disease bearing hallmarks of Th2 deviation. ${ }^{1}$ As part of these studies, we set out to concurrently delete the cognate receptors for these cytokines-IFN $\gamma \mathrm{RI}$ and IL17RA, respectively. In the process of establishing IFN $\gamma \mathrm{RI}^{-/-} \mathrm{IL}_{17 \mathrm{RA}^{-/-}}$ (GRAKO) double-knockout mice, we found that these mice began spontaneously developing oral abscesses which, on testing, were determined to be uncontrolled infections with Staphylococcus aureus.
S. aureus is a Gram-positive member of the Firmicutes phylum, commonly found at cutaneous and mucosal surfaces in healthy mammalian hosts as a commensal organism. However, acquisition of virulence factors or immune compromise of the host can lead to opportunistic invasion and infection. ${ }^{2}$ Patient infections with $S$. aureus in hospital

\footnotetext{
Supported by NIH National Heart, Lung, and Blood Institute grants R01HL118183 (D.C.) and R01HL113008 (D.C.), the Gilead Sciences Research Scholars program (J.G.B.), and the American AutoimmuneRelated Diseases Association (J.G.B.). N.L.D. is supported by predoctoral fellowship 15PRE25400010 from the American Heart Association and the Richard J. and Margaret Conn Himelfarb Student Support Fund. X.H. is the O'Leary-Wilson Fellow in Autoimmune Disease Research at the Johns Hopkins Autoimmune Disease Research Center.

Disclosures: Amgen provided IL17RA ${ }^{-1-}$ BALB/c founder mice.
} 
and community settings are a growing problem, particularly given the ongoing emergence of antibiotic resistance. ${ }^{3}$

Clear roles for IL-17 signaling and associated pathways in staphylococcal infections have been well established in experimental infection models. ${ }^{4}$ In these studies, expression of IL-17 by cutaneous $\gamma \delta$ cells was essential in supporting rapid local recruitment of neutrophils, which in turn supported Th17 differentiation through IL-1 $\beta$, forming a positive feed-forward circuit at the site of infection. ${ }^{5,6}$ However, unambiguous protective roles for IFN- $\gamma$ from $S$. aureus have not been as clearly delineated, in part because many of these studies preceded the Th17 paradigm. $^{7-10}$

The spontaneous staphylococcal disease of our IFN $\gamma \mathrm{RI}^{-1-}$ IL17RA ${ }^{-/-}$model pointed us toward a novel role for IFN- $\gamma$ in this host defense process with a requisite interaction with IL-17-dependent signaling. The purpose of this work was to first characterize the disease of IFN $\gamma \mathrm{RI}^{-1-}$ IL17RA $^{-1-}$ double-knockout mice and then to examine their immunologic phenotype and function to elucidate the mechanisms underlying the severe spontaneous oral infections of IFN $\gamma \mathrm{RI}^{-/-} \mathrm{IL}_{17 \mathrm{RA}^{-1-}}$ mice. From these studies, we find evidence for novel collaborative interactions between neutrophils and macrophages, as effectors of immunity driven by IL-17 and IFN- $\gamma$ signaling, respectively.

\section{Materials and Methods}

\section{Mice}

Wild-type BALB/cJ mice and founder IFN $\gamma \mathrm{RI}^{-/-} \mathrm{BALB} / \mathrm{c}$ mice were commercially sourced (The Jackson Laboratory, Bar Harbor, ME). IL17RA ${ }^{-1-}$ BALB/c founder mice were the generous provision of Amgen (Thousand Oaks, CA), through Dr. Jay Kolls (University of Pittsburgh, Pittsburgh, PA). To establish the IFN $\gamma \mathrm{RI}^{-/-} \mathrm{IL} 17 \mathrm{RA}^{-/-}$double-knockout strain, IFN $\gamma \mathrm{RI}^{-1-}$ and IL17RA ${ }^{-1-}$ mice were intercrossed for one generation. [F1] hybrid progeny were further backcrossed to the IFN $\gamma \mathrm{RI}^{-1-}$ background to fix the Ifngrl locus at homozygosity of the knockout allele, then intercrossed to generate IFN $\gamma \mathrm{RI}^{-1-} \mathrm{IL}^{2} \mathrm{RAA}^{-1-}$ double-knockouts. Following emergence of the disease phenotype, the colony was maintained at hemizygosity at the Ill7ra locus to limit disease among breeders. For some experiments, Thy $1.1^{+}$BALB/c congenic mice were substituted for wild-type controls, and IL17RA ${ }^{-1-}$ CD45. $1^{+}$mice for IL17RA ${ }^{-1-}$ mice. All mice were maintained in the Johns Hopkins University School of Medicine specific pathogen-free vivarium. Experiments were conducted in compliance with the Animal Welfare Act and the principles set forth in the Guide for the Care and Use of Laboratory Animals. ${ }^{11}$ All methods and protocols were approved by the Animal Care and Use Committee of the Johns Hopkins University.

\section{Macrophage and Neutrophil Depletions}

For mononuclear phagocyte system (MPS) depletions, clodronate- and phosphate-buffered saline-loaded liposomes
(ClondronateLiposomes.com, Amsterdam, the Netherlands) were administered intraperitoneally, $200 \mu \mathrm{L}$ per mouse, twice per week, for up to 6 weeks. For neutrophil depletions, IFN $\gamma \mathrm{RI}^{-1-}$ mice were administered $500 \mu \mathrm{g}$ of anti-Ly6G monoclonal antibody (mAb) 1A8 (or isotype control rat IgG2a mAb 2A3; Bio X-Cell, West Lebanon, $\mathrm{NH}$ ) intraperitoneally on days 0 and 2 , followed by $250 \mu \mathrm{g}$ maintenance doses b.i.d. for 4 weeks. Pathology, cytometry, and microbiology were performed at termination of the experiment.

\section{Histopathology}

Tissues were fixed in SafeFix (Thermo Fisher Scientific, Waltham, MA) and embedded, and 5- $\mu \mathrm{m}$ step sections were cut and stained with hematoxylin and eosin (H\&E), or Brown $\&$ Brenn (Histoserv, Germantown, MD). Scoring was based on a weighted composite score of six criteria, each graded on a 0 to 4 scale: presence of abscess, bacteria, infiltration with polymorphonuclear or mononuclear cells, and inflammatory involvement of epidermis or dermis - the first two weighted doubly, then added, resulting in a 1 to 32 scale.

\section{Flow Cytometry}

Oral tissues were digested in $10 \mathrm{mg}$ Liberase TL (Roche, Basel, Switzerland), $100 \mathrm{mg}$ Dispase (Roche), $100 \mathrm{mg}$ collagenase II (Worthington Biochemical Corporation, Lakewood, NJ), and $0.1 \mathrm{mg} / \mathrm{mL}$ DNase I (Worthington Biochemical Corporation) for 90 minutes at $37^{\circ} \mathrm{C}$, followed by suspension in gentle MACS C Tubes (Miltenyi Biotec, Gladbach, Germany). Lymph node (LN) cells and splenocytes were also extracted into single-cell suspension, and red blood cells were lyzed by $<5$ minutes of incubation in ammonium-chloride-potassium lysis buffer (Quality Biological, Gaithersburg, MD). Before surface staining, viability was determined by LIVE/DEAD staining according to the manufacturer's instructions (Molecular Probes, Eugene, OR). Cells were washed, and Fc $\gamma$ RII/III was blocked with $\alpha \mathrm{CD} 16 / 32 \mathrm{mAb} 93$ (eBioscience, San Diego, CA). Surface markers were stained with fluorochromeconjugated mAbs: CD11b mAb M1/70, CD45RB mAb C363-16A, Siglec F mAb E50-2440 (BD Biosciences, San Jose, CA); CD4 mAb RM4-5, CD8 $\alpha$ mAb 53-6.7, CD54/ ICAM1 mAb YN1/1.7.4, CD62L mAb MEL-14, CD64 mAb X54-5/7.1, CD183/CXCR3 mAb CXCR3-173, CD206/ M $\varphi$ MR mAb C068C2, FceRI $\alpha$ mAb MAR1, Ly6C mAb HK1.4, Ly6G mAb 1A8 (BioLegend, San Diego, CA); CD3 $\varepsilon$ mAb 145-2C11, CD44 mAb IM7, F4/80 mAb BM8, TCR $\beta$ mAb H57-597, TCR $\gamma \delta$ mAb GL3 (eBioscience); CD45 mAb MCD4517, and CD45R/B220 mAb RA3-6B2. After washing, cells were fixed (BD Biosciences), or for intracellular, intranuclear staining with ROR $\gamma \mathrm{t}$ mAb Q31-378 (BD Biosciences), fixed and permeabilized with transcription factor-specialized buffers (eBioscience). Samples were acquired on a four laser custom LSR II cytometer running FACSDiva 6.0 (BD Immunocytometry, San Jose, CA). Data were analyzed with FlowJo version 10.8 (TreeStar Software, Ashland, OR). 


\section{Recall Stimulations}

Superficial cervical LNs (scLNs) were resected, made into single-cell suspensions, and washed generously. LN cells $\left(2 \times 10^{6}\right)$ were plated in complete Dulbecco's modified Eagle's medium with $2.5 \times 10^{6}$ heat-killed $S$. aureus (InvivoGen, San Diego, CA). Supernatants were collected after 48 hours and stored at $-80^{\circ} \mathrm{C}$ before interrogation by Linco multiplex cytokine assays (Millipore, Billerica, MA) or enzyme-linked immunosorbent assay (ELISA).

\section{ELISA and Linco}

Tissues were snap-frozen, stored at $-80^{\circ} \mathrm{C}$, homogenized in minimal essential medium (MEM) $+2 \%$ fetal bovine serum FBS, and stored at $-80^{\circ} \mathrm{C}$ until used in ELISA or Linco assays. Homogenate cytokine levels were normalized to wet sample weights. Linco multiplex cytokine assays (Millipore) were used according to the manufacturer's instructions and acquired on a Luminex (Austin, TX) xMAP reader. Total serum IgG and IgE (BD Biosciences) and mouse myeloperoxidase (Abcam, Cambridge, MA) were determined by quantitative sandwich ELISA against standard curves, according to manufacturers' instructions.

\section{Microbiology}

Oral swabs were obtained with Copan eSwab kits and were subjected to broth-enrichment culture for Staphylococcus spp. as previously described. ${ }^{12}$ Isolates from these swabs were subjected to species identification and strain characterization by PCR. ${ }^{13-17}$ For in vitro killing assay, primary bone marrow neutrophils isolated by paramagnetic negative selection (Miltenyi Biotec) were co-cultured for up to 4 hours with live $S$. aureus at MOI $=1$. Total colony counts of water-lyzed wells from each time point were plated for enumerating colony-forming units.

\section{Statistical Analysis}

Statistical analyses were performed on multiple group comparisons as described in the figure legends (GraphPad Prism version 6.0, San Diego, CA; StatPlus:mac Pro; AnalystSoft, Walnut, CA; Microsoft Excel 2016 version 15.24, Microsoft, Redmond, WA).

\section{Results}

\section{IFN $\gamma \mathrm{RI}^{-/-}$IL17RA $^{-/-}$BALB/cJ Mice Develop Extensive Perioral Infection with $S$. aureus}

We observed periocular blepharitis developing in our IL17RA $^{-1-}$ colony with varying penetrance, beginning at roughly 3 to 4 months of age (Figure 1, A and E). Similar phenotypes have been described in patients with defects in IL17RA or Act1 ${ }^{18,19}$ Veterinary clinical calls from the Research Animal Resources division of Johns Hopkins
University School of Medicine had alerted us to the presence of facial growths developing in our newly established IFN $\gamma \mathrm{RI}^{-1-} \mathrm{IL} 17 \mathrm{RA}^{-1-}$ mouse colony (Figure 1, B-F).

Over time, the abscesses of IFN $\gamma \mathrm{RI}^{-/-} \mathrm{IL} 17 \mathrm{RA}^{-1-}$ mice led to cachexia (Figure $1 \mathrm{G}$ ), presumably because the abscesses interfered with normal feeding. IFN $\gamma \mathrm{RI}^{-1-}$ IL17RA ${ }^{-1-}$ mice further demonstrated splenomegaly at the time of sacrifice compared with controls (Figure 1H), probably an indicator of their uncontrolled spontaneous infection. The time course of onset for the oral abscesses is depicted in Figure 1I. IFN $\gamma \mathrm{RI}^{-1-} \mathrm{IL}_{17 \mathrm{RA}^{-1-}}$ mice began manifesting gross lesions between 6 to 10 weeks of age, increasing in severity over time. Comparing the slope of this regression with the control genotypes demonstrated significant progression of oral lesions in the IFN $\gamma \mathrm{RI}^{-1-}$ $\mathrm{IL17RA}^{-1-}$ strain $(P=0.0015)$, in a manner not shared by the progression of the orbital lesions (not shown). At ages $>20$ weeks, abscesses were often severe enough to warrant euthanasia of IFN $\gamma \mathrm{RI}^{-1-} \mathrm{IL}_{17 \mathrm{RA}^{-1-}}$ mice on consultation with veterinarians. Both male and female mice were affected with comparable incidence and severity (Supplemental Figure S1, A and B) and time course (not shown).

Methicillin-susceptible S. aureus was isolated and PCRconfirmed from the oral mucosa of nine of nine symptomatic mice tested (Figure 1J). ${ }^{12,15}$ All isolates were negative for $m e c A / C$, USA300, and $l u k-P V$ genes. ${ }^{16,20}$ In a subset of three confirmed methicillin-susceptible $S$. aureus isolates selected for testing, all were scn positive and were spa-type $\mathrm{t} 774$. Although the identified strain did not match the dominant human community clone (PVL+ USA300) circulating in the United States, the presence of the scn gene in tested isolates indicates likely human origin and not a mouse-adapted strain. ${ }^{21}$ We further found expression of superoxide dismutase $\mathrm{A}(\operatorname{sod} A)$ by quantitative real-time PCR from bulk genomic DNA in oral tissues (Figure 1K). Single-knockout IL17RA ${ }^{-1-}$ and IFN $\gamma \mathrm{RI}^{-/-}$controls, as well as wild-type mice, lacked similar pathology (Figure 1, E-K) (representative gross pathology for controls is not shown). Together, these data support that defects of both IFN- $\gamma$ and IL-17 signaling pathways are essential contributors to the disease pathology of the IFN $\gamma \mathrm{RI}^{-/-} \mathrm{IL} 17 \mathrm{RA}^{-/-}$strain. Moreover, these pathways were collaborative in a manner in which their combined defect was sufficient for opportunistic infection.

We examined net Ig levels in the sera of these mice, as general markers of immune status, but more specifically, due to previous evidence of Th2 deviation in our investigations of IFN $\gamma^{-1-} \mathrm{IL}_{17 \mathrm{~A}^{-1-}}$ mice. ${ }^{1}$ By absolute quantitation through sandwich ELISA methods, we observed elevated serum IgG levels in IFN $\gamma \mathrm{RI}^{-/-} \mathrm{IL}_{17 R A^{-1-}}$ and IL17RA ${ }^{-1-}$ mice (Figure 1L). However, quantitation of serum Ig demonstrated specific elevation of total IgE only in IFN $\gamma \mathrm{RI}^{-1-} \mathrm{IL} 17 \mathrm{RA}^{-1-}$ mice (Figure 1M). From these data, we conclude that spontaneous staphylococcal infection of IFN $\gamma^{-l-} \mathrm{IL}_{17 \mathrm{~A}^{-1-}}$ mice recapitulates the susceptibility of hyper IgE patients to staphylococcal infection, possibly presenting a novel model of immunodeficiency processes in that disease. 
IL17RA $^{-1-}$

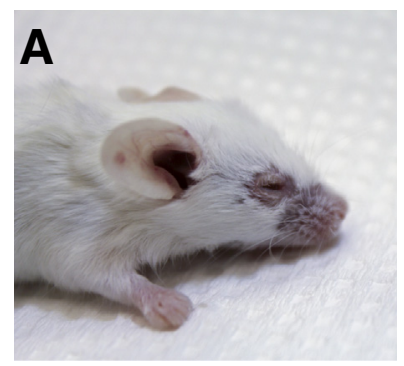

male

12 weeks

grade 0.5

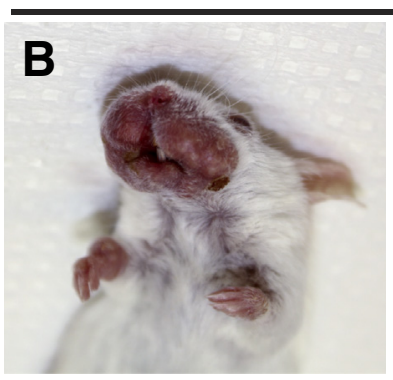

female

10 weeks

grade 2
IFNyRI ${ }^{-1-I L 17 R A}$ I- $^{-1}$

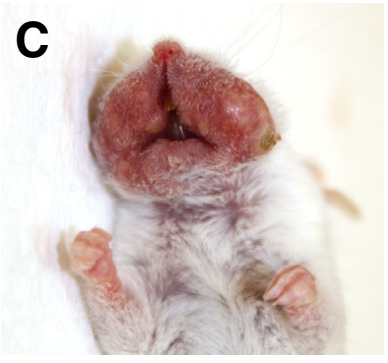

male

25 weeks

grade 3

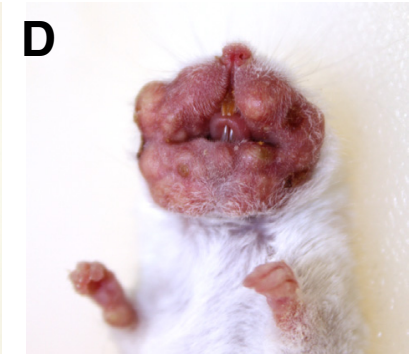

male

25 weeks grade 4

E orbital lesions

F oral lesions

G bodyweight

H spleen weight
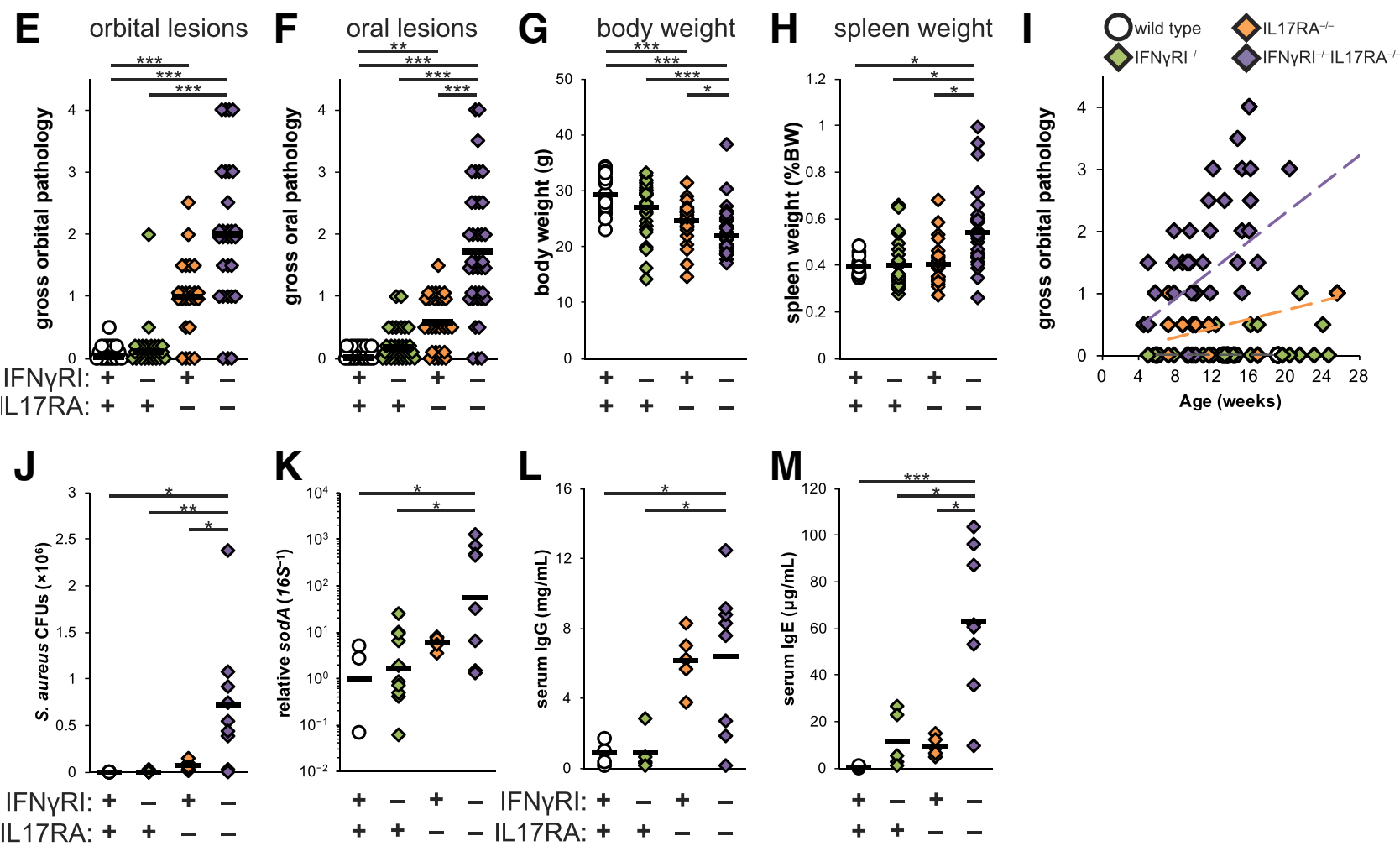

Figure 1 IFN $\gamma \mathrm{RI}^{-/} \mathrm{IL}_{17 \mathrm{RA}^{-/-}}$mice develop spontaneous staphylococcal perioral abscesses. A-D: Representative photography of disease phenotypes: periocular inflammation of IL17RA ${ }^{-/-}$BALB mice (A), and the perioral abscesses of IFN $\gamma \mathrm{RI}^{-/-}{ }^{- \text {IL17RA }^{-/}}$mice (B-D). E and F: Gross pathologic examination of orbital $(\mathbf{E})$ and oral $(\mathbf{F})$ lesions in IFN $\gamma \mathrm{RI}^{-/-}$IL17RA ${ }^{-/-}$mice and controls. Gross pathology was scored on a semiquantitative 0 to 4 scale. $\mathbf{G}$ and $\mathbf{H}$ : Body $(\mathbf{G})$ and spleen $(\mathbf{H})$ weight, expressed as a percentage of total body weight, at time of sacrifice. Statistics for discontinuous nonparametric data are by KruskalWallis analysis of variance. I: Time course of disease onset, depicting gross oral pathology scores as a function of age at sacrifice. Regression lines for each genotype are color-coded as shown. J: Oral colonization of IFN $\gamma \mathrm{RI}^{-/-}{ }^{-} \mathrm{IL}_{17 R A^{-/-}}$mice and controls by Staphylococcus aureus, represented as CFUs of S. aureus from oral swabs. K: Semiquantitative real-time PCR of S. aureus sodA from oral tissue. Statistics are by one-way analysis of variance, followed by post hoc pairwise comparisons by Tukey-Kramer method. $\mathbf{L}$ and $\mathbf{M}$ : Quantitation of total serum immunoglobulins by sandwich ELISA. Individual mice are represented by diamonds or circles; means of groups by bars. Statistically significant pairwise comparisons are denoted between relevant groups. $n=21$ IFN $\gamma \mathrm{RI}^{-/}{ }^{-} \mathrm{IL}_{17 R A}{ }^{-1-}$ mice; $n=14$ single-knockout IL17RA ${ }^{-/}$mice; $n=14 \mathrm{IFN} \gamma \mathrm{RI}^{-/}$mice; $n=12$ wild-type control mice $(\mathrm{I}) .{ }^{*} P<0.05, * * P \leq 0.01$, and ${ }^{* * * P} \leq 0.001$. BW, body weight; CFU, colony-forming unit; ELISA, enzyme-linked immunosorbent assay; IFN, interferon.

Histopathologic Features of Infectious Lesions in IFN $\gamma \mathrm{RI}^{-/-} \mathrm{IL} 17 \mathrm{RA}^{-/-}$Mice

Histopathologic examination of oral tissues in control wild-type or IFN $\gamma \mathrm{RI}^{-I-}$ mice revealed no or limited oral inflammation (Figure 2, A, B, E and F). IL17RA ${ }^{-1-}$ control mice, demonstrated signs of inflammation in the dermis that appeared to be consistent with folliculitis (Figure 2, C and G). The oral abscesses in IFN $\gamma \mathrm{RI}^{-1-} \mathrm{IL}_{17 \mathrm{RA}^{-/}}$mice demonstrated extensive infiltration with mononuclear and polymorphonuclear cells, generally surrounding large heterogeneous eosin-staining material featuring large filamentous 

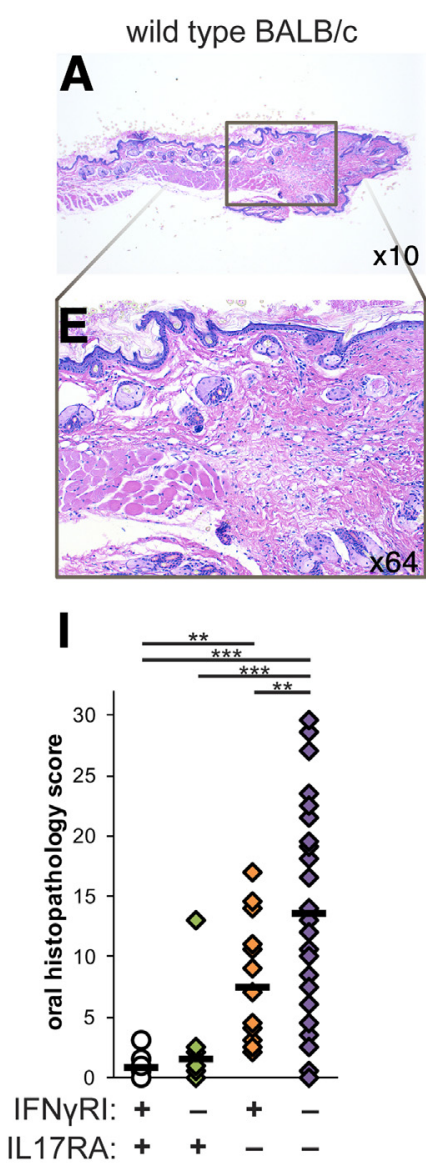

\section{B}

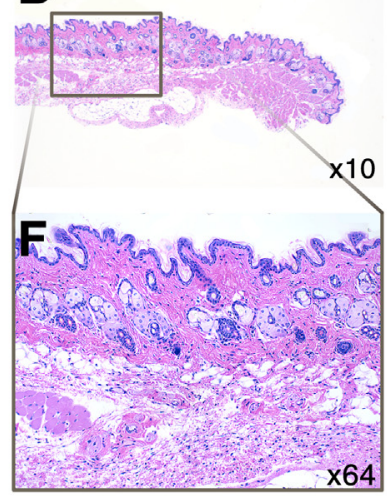

$\mathbf{J}$

Brown \& Brenn (gram stain)
C

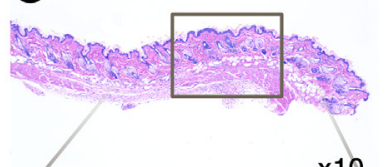

D

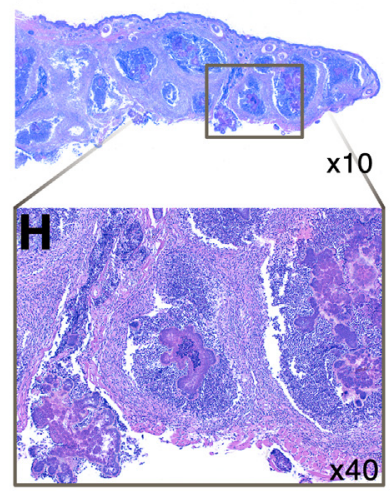

$\times 64$

N

hematoxylin \& eosin

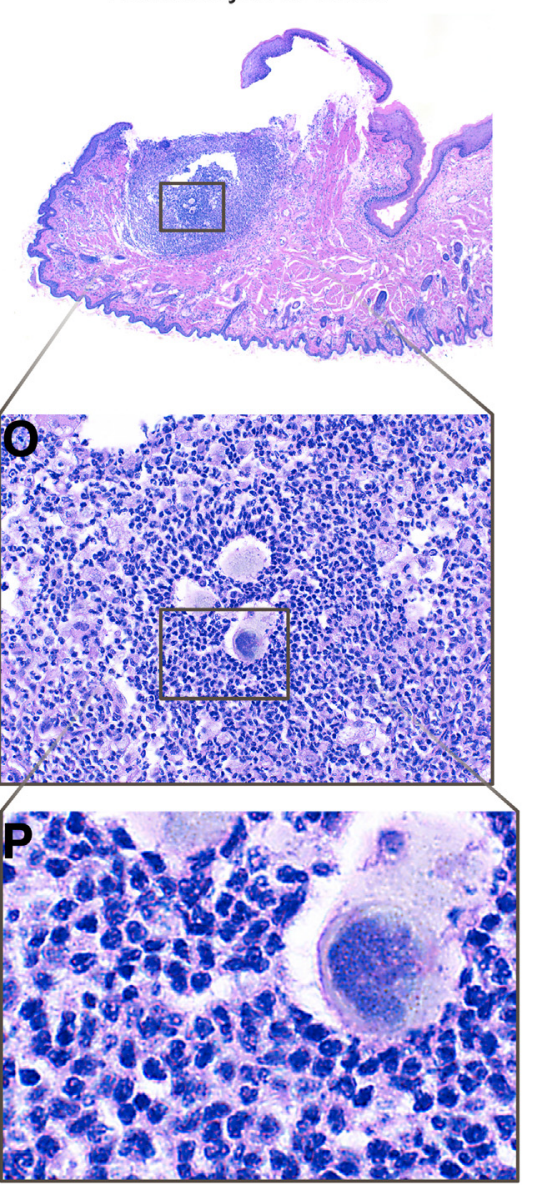

Figure 2 Histopathologic examination of abscesses of IFN $\gamma \mathrm{RI}^{-/-} \mathrm{IL}_{17 R A^{-/}}$mice reveals extensive surrounding polymorphonuclear infiltration. A-H: Representative histopathology of perioral tissues from control genotypes and IFN $\gamma \mathrm{RI}^{-/}{ }^{-} \mathrm{IL}_{17 \mathrm{RA}^{-/}}$mice. Boxed areas in A-D correspond to highermagnification images in $\mathbf{E}-\mathbf{H}$. I: Scoring of histopathologic severity of perioral tissues. Individual mice are represented by diamonds or circles. Gramstaining of affected IFN $\gamma \mathrm{RI}^{-/}{ }^{-} \mathrm{IL}_{17 R A^{-/-}}$perioral tissues by Brown \& Brenn $(\mathbf{J}-\mathbf{M})$ against hematoxylin and eosin serial sections (N-P). Boxed area in $\mathbf{J}$ is enlarged in $\mathbf{~}$; boxed areas in $\mathbf{K}$ are enlarged in $\mathbf{L}$ and $\mathbf{M}$. Boxed area in $\mathbf{N}$ is enlarged in $\mathbf{0}$; boxed area in $\mathbf{0}$ is enlarged in $\mathbf{P}$. Statistics are by one-way analysis of variance, followed by post hoc pairwise comparisons by Tukey-Kramer method. Statistically significant pairwise comparisons are denoted between relevant groups. ${ }^{* * P} \leq 0.01,{ }^{* * *} P \leq 0.001$. Original magnification: $\times 10(\mathbf{N}) ; \times 160(\mathbf{0}) ; \times 640(\mathbf{M}$ and $\mathbf{P})$. IFN, interferon.

hematoxylin-staining inclusions (Figure 2, D and H). Generally, lesions appeared to be more associated with the oral mucosa of these tissues than the keratinaceous epidermal layers. Quantitative, subjective measurement of the histopathologic severity of these abscesses supported severely uncontrolled infection of oral tissues in IFN $\gamma \mathrm{RI}^{-/-} \mathrm{IL}_{17 \mathrm{RA}^{-I-}}$ mice (Figure 2I).

Brown \& Brenn Gram-staining of affected oral tissues in $\mathrm{IFN}_{\gamma} \mathrm{RI}^{-1-} \mathrm{IL}_{17} \mathrm{RA}^{-1-}$ mice revealed clusters of 
Gram-positive cocci deep within the abscess (Figure 2, $\mathrm{J}-\mathrm{L}$ ). These clusters also stained positive with Grocott's metheneamine silver (not shown). Serial section staining with $\mathrm{H} \& \mathrm{E}$ indicated these Gram-positive bacterial clusters were immediately bound by extensive polymorphonuclear and mononuclear inflammatory infiltrates (Figure 2, N-P). In addition, diffuse, isolated Gram-staining cocci could be seen elsewhere in the inflamed region (Figure $2 \mathbf{M}$ ), further indicative of insufficient control of bacterial invasion and outgrowth in the oral mucosa of IFN $\gamma \mathrm{RI}^{-/-} \mathrm{IL} 17 \mathrm{RA}^{-/-}$ mice.

We expanded our histopathologic analysis to other tissues, to determine whether staphylococcal infection had trafficked to other tissues or become systemic. We did not observe clear signs of disseminated infection in lung, liver, or spleen (Supplemental Figure S1, C-G). In mice with highly advanced severe oral lesions, we observed limited periportal hepatic inflammatory foci (Supplemental Figure S1, C and D) and pyogranulomatous infiltrates in lung (Supplemental Figure S1G). These signs of advancing systemic inflammation or disseminating infection generally appeared only in older mice with more severe oral pathology. We interpreted the involvement of these organs as spillover from severe oral infections.

In addition to the perioral lesions, we also observed smaller purulent abscesses developing in the forelimbs of IFN $\gamma \mathrm{RI}^{-1-} \mathrm{IL} 17 \mathrm{RA}^{-1-}$ mice (Supplemental Figure S1, $\mathrm{H}-\mathrm{M}$ ) and none of the control genotypes (not shown). Generally, these forelimb manifestations were not as prevalent, appearing largely in older mice with more severe perioral abscesses. Forelimb abscesses were often bilateral, but not necessarily symmetric. Histopathologic examination revealed Gram-positive abscesses developed in the subdermis, without invasion into the underlying musculoskeletal structures or synovia. It should also be noted that these lesions do not appear in our colony of IFN $\gamma^{-1-} \mathrm{IL} 17 \mathrm{~A}^{-1-}$ mice, ${ }^{1}$ indicating that an IL-17 family member other than IL-17A is the necessary ligand in native defense to $S$. aureus invasion in the oral mucosa.

\section{Cellular Mediators of Staphylococcal Lesions in} IFN $\gamma \mathrm{RI}^{-/}{ }^{-}$IL17RA $^{-/-}$Mice: Compromised Neutrophil Function in the Absence of IL-17 Signaling

We used cytometric methods to interrogate the infiltrate of affected perioral tissues, with particular attention toward effector populations. Clear infiltration of these tissues by $\mathrm{CD} 45^{+}$leukocytes was evident in IFN $\gamma \mathrm{RI}^{-/-} \mathrm{IL} 17 \mathrm{RA}^{-/-}$ mice (Figure 3A). Consistent with histopathologic data, there was also evidence of mild inflammatory infiltration of perioral tissues in IL17RA ${ }^{-1-}$ mice, although not to the extreme degree of IFN $\gamma \mathrm{RI}^{-/}{ }^{-1 L} 17 \mathrm{RA}^{-1-}$ mice.

By far, the most abundant infiltrating leukocyte was Ly6G ${ }^{\text {hi }}$ neutrophils (Figure 3B), consistent with the extensive polymorphonuclear infiltrates observable by histopathology. Other granuloid cell types, including Siglec $\mathrm{F}^{+}$ eosinophils (Figure 3C) and FceRI $\alpha^{+}$mast cells and basophils (Figure 3D), were also elevated in the affected oral tissues of IFN $\gamma \mathrm{RI}^{-1-} \mathrm{IL} 17 \mathrm{RA}^{-1-}$ mice, although not to the same extreme degree as neutrophils and not significantly in comparison with IL17RA ${ }^{-1-}$ controls.

The extensive neutrophil infiltration of infected oral tissues of IFN $\gamma \mathrm{RI}^{-1-} \mathrm{IL}_{17 \mathrm{RA}^{-1-}}$ mice was at odds with welldescribed roles for neutrophils in control of experimental infection with $S$. aureus. ${ }^{6,22}$ The abundance of neutrophils despite ongoing infection suggested functional defects (Figure 3, E-H). To address the role of neutrophils in native oral defense to $S$. aureus, IFN $\gamma \mathrm{RI}^{-/-}$mice were depleted of neutrophils by extended treatment over 4 weeks with the $\mathrm{mAb} 1 \mathrm{~A} 8$. At the end of this neutrophil depletion course, mild subdermal inflammation was observed (Supplemental Figure S2), resembling the mild inflammation observed in IL17RA ${ }^{-l-}$ controls.

As an indicator of neutrophil function in the affected perioral tissues, we interrogated homogenates of cheek tissues by quantitative sandwich ELISA for the canonical neutrophil granule product myeloperoxidase (MPO). Like many of the other cytokine analytes (Supplemental Figure S3), MPO levels were highest in IFN $\gamma \mathrm{RI}^{-l-}$ IL17RA ${ }^{-1-}$ mice (Figure 3I), a probable indicator of persistent infection. These data were normalized to sample weight, similar to the cytometric analyses presented in Figure 3B. Because of this common normalization factor, we could approximate a ratio of MPO levels to neutrophil numbers - as an indicator of how much MPO each neutrophil might be producing in situ. From this calculation, we observed diminished per-cell equivalents of MPO in the oral tissues of IFN $\gamma \mathrm{RI}^{-1-} \mathrm{IL}_{17 \mathrm{RA}^{-1-}}$ and $\mathrm{IL}_{17 \mathrm{RA}^{-1-}}$ mice (Figure 3J). Experimental in vitro co-culture assays with live $S$. aureus (Figure $3 \mathrm{~K}$ ) did not demonstrate defective killing with IFN $\gamma \mathrm{RI}^{-1-}{ }^{\mathrm{IL}} 17 \mathrm{RA}^{-1-}$ bone marrow neutrophils. Altogether, these data support that IL-17 signaling predominates control of neutrophilic recruitment and function in host defense to Staphylococcus.

\section{Cytokine and Chemokine Mediators of Staphylococcal Lesions in IFN $\gamma \mathrm{RI}^{-/}{ }^{-} \mathrm{IL}_{17 R A}{ }^{-/-}$Mice}

Neutrophil recruitment is a canonical function for IL-17 signaling, but it fails to explain the involvement of IFN- $\gamma$ in defense against Staphylococcus, or why IFN $\gamma \mathrm{RI}^{-/-}$ IL17RA ${ }^{-1-}$ mice progress to uncontrolled infection. To better understand the mechanism underlying the failure of IFN $\gamma \mathrm{RI}^{-1-} \mathrm{IL}^{2} \mathrm{R} \mathrm{RA}^{-1-}$ mice to control staphylococcal infection, we examined the expression of various cytokine and chemokine mediators by interrogating homogenates of perioral tissues by multiplex cytokine array. By and large, most cytokine analytes were highest in the IFN $\gamma \mathrm{RI}^{-/-}$ IL17RA ${ }^{-/-}$mice (Supplemental Figure S3), compared with single-knockout and wild-type controls, which we interpret to be a response to ongoing infection.

Grouping these analytes functionally, we observed increased levels of the proinflammatory cytokines IL- $1 \beta$, IL- 6 , and tumor 
A

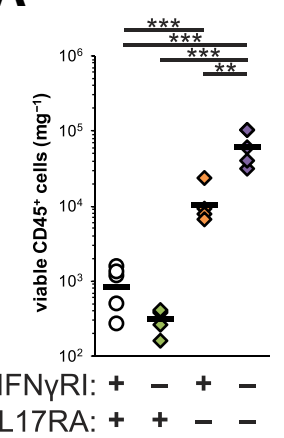

E

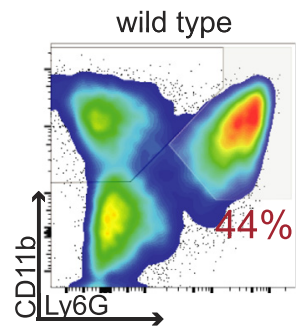

B

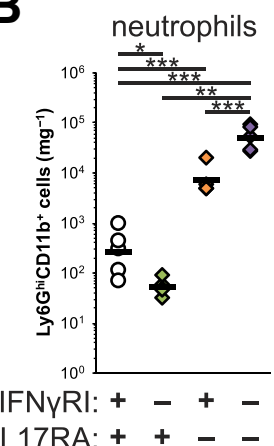

F

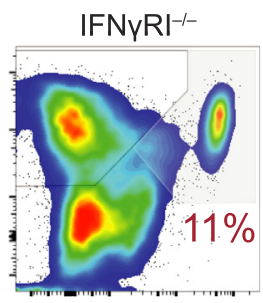

C

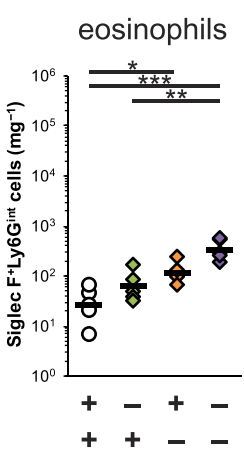

G

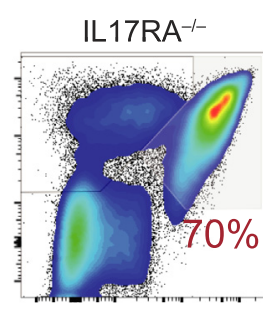

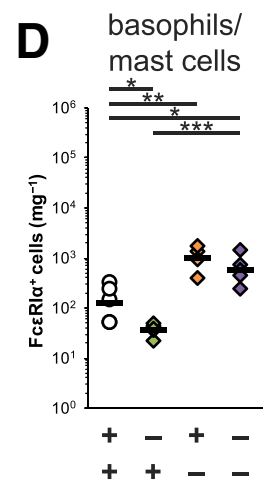

H

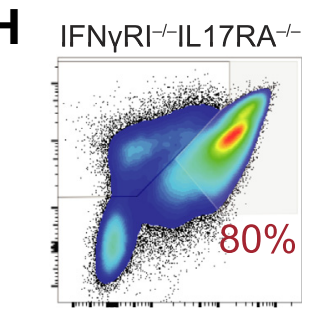

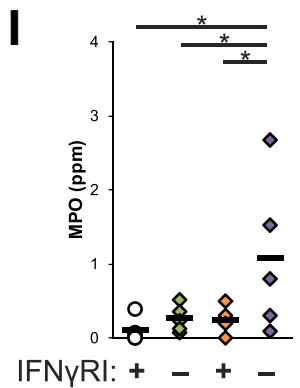

IL17RA: + + - -
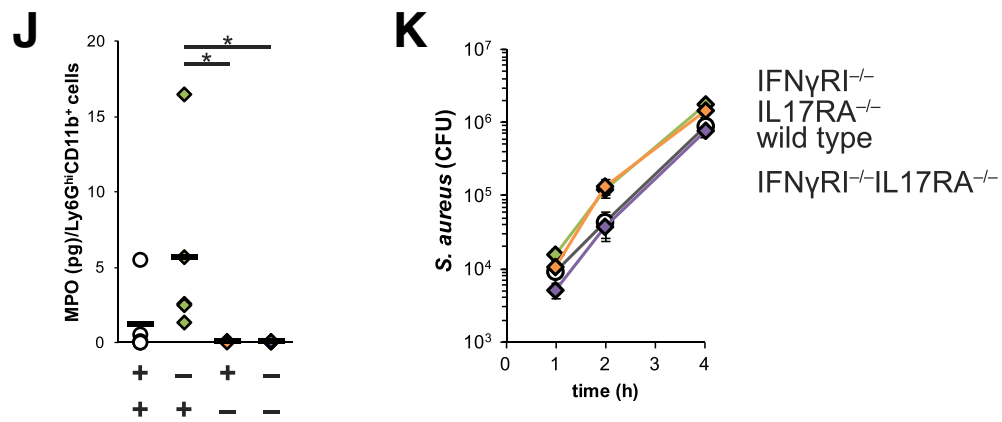

Figure 3 Defects in neutrophils as cellular mediators of host defense to Staphylococcus aureus in oral tissues of IFN $\gamma \mathrm{RI}^{-/-} \mathrm{IL}^{-17 R A^{-/-}} \mathrm{mice}^{-}$A: Total oral CD45 $5^{+}$leukocytes, expressed as absolute numbers, normalized to sample weight. B-D: Ly6G ${ }^{\text {hi }}{ }^{2} 111 b^{+}$neutrophils (B), Siglec $F^{+}$Ly6G ${ }^{\text {int }}$ eosinophils $(\mathbf{C})$, and $\mathrm{Fc \varepsilon RI} \alpha^{+}$mast cells and basophils (D) infiltrating oral tissues expressed as absolute numbers, normalized to sample weight. E-H: Representative bivariate plots of viable $\mathrm{CD}_{4} 5^{+}$-gated events in oral tissues depict concatenates of each group. I and J: Myeloperoxidase levels in perioral tissue homogenates by quantitative sandwich ELISA, normalized by sample weight (I), and in ratio to total neutrophil counts from Figure 3B (J). Statistics are by Fisher's LSD. K: In vitro killing of S. aureus by neutrophils. Individual mice are represented by diamonds or circles; means of groups by bars. Statistically significant pairwise comparisons are denoted between relevant groups. ${ }^{*} P<0.05,{ }^{* *} P \leq 0.01$, and ${ }^{* * *} P \leq 0.001$. ELISA, enzyme-linked immunosorbent assay; IFN, interferon; LSD, least significant difference; MPO, myeloperoxidase.

necrosis factor- $\alpha$ specifically in IFN $\gamma \mathrm{RI}^{-1-} \mathrm{IL} 17 \mathrm{RA}^{-/-}$mice (Supplemental Figure S3, A-C). Similarly, we observed production of the neutrophilic chemokine CXCL1/KC, and the neutrophil growth factors granulocyte colony-stimulating factor (CSF) and granulocyte-macrophage CSF in the affected perioral tissues of IFN $\gamma \mathrm{RI}^{-1-} \mathrm{IL}_{17 \mathrm{RA}^{-l-}}$ mice (Supplemental Figure S3, D-F). Interestingly, we observed increased expression of IL-17A in both the single-knockout IL17RA ${ }^{-1-}$ and double-knockout IFN $\gamma \mathrm{RI}^{-/-} \mathrm{IL} 17 \mathrm{RA}^{-1-}$ strains, suggesting compensatory overexpression in the absence of IL-17 signaling (not shown). We further observed increased expression of chemokines associated with monocyte and macrophage recruitment, including chemokine ligand (CCL)2, CCL3, and CCL5 (Supplemental Figure S3, G-I).

In studies in autoimmune heart disease, we found that dual deletion of the cytokine ligands IFN- $\gamma$ and IL-17A led to Th2 deviation. ${ }^{1}$ Interrogating Th2-associated cytokines in the perioral tissues of $\mathrm{IFN} \gamma \mathrm{RI}^{-/}{ }^{-} \mathrm{IL}_{17 \mathrm{RA}}{ }^{-1-}$ mice, we observed increased production of IL-4, IL-10, and a trend for CCL11/eotaxin-1 (Supplemental Figure S3, $\mathrm{J}-\mathrm{L}$ ), but no appreciable levels of IL-5 or IL-13 (not shown).

To make functional sense of these data, we further conceptually reorganized analytes according to one of four patterns of expression, depending on their correlation to genotype. Largely, most analytes interrogated demonstrated highest production in IFN $\gamma \mathrm{RI}^{-1-} \mathrm{IL} 17 \mathrm{RA}^{-/-}$mice, a finding we interpret to signify ongoing infection of these mice. A second grouping of cytokines and chemokines were elevated in both double-knockout and IL17RA ${ }^{-1-}$ mice, including CCL2/monocyte chemoattractant protein-1, CCL5/regulated on activation normal $\mathrm{T}$ cell expressed and secreted, 
CXCL10/IFN- $\gamma$-induced protein 10, and IL-17A. We interpret IFN $\gamma \mathrm{RI}^{-/-} \mathrm{IL} 17 \mathrm{RA}^{-1-}$ mice tracking alongside the IL17RA ${ }^{-/-}$strain to indicate that expression of these cytokines was under the predominant control of IL-17 signaling. A fewer number of analytes, exemplified by granulocytemacrophage CSF, tracked with the IFN $\gamma \mathrm{RI}^{-1-}$ singleknockout control.

However, only one chemokine demonstrated lower levels specifically in IFN $\gamma \mathrm{RI}^{-/}{ }^{-} \mathrm{IL} 17 \mathrm{RA}^{-/-}$mice, compared with control strains: CXCL9/Mig (Figure 4A), implicating this chemokine in functional control of mucosal $S$. aureus. The similarly regulated chemokine CXCL10/IFN- $\gamma$-induced protein 10 did not demonstrate this pattern (Figure 4B). As further confirmation, we observed a similar defect in CXCL9/Mig production in the supernatants of lymphocytes from the scLNs, restimulated with heat-killed $S$. aureus (Figure 4C).

\section{Cellular Mediators of Staphylococcal Lesions: Defects of T-Cell Programing and Recruitment}

In addition to the splenomegaly in IFN $\gamma \mathrm{RI}^{-1-} \mathrm{IL}_{17 \mathrm{RA}}{ }^{-1-}$ mice described above, we further observed lymphadenopathy, specifically in the scLNs (Figure 4D). Enumerating total numbers of lymphocytes, we observed expansion of all lymphoid subpopulations in the draining LNs of IFN $\gamma \mathrm{RI}^{-1-} \mathrm{IL} 17 \mathrm{RA}^{-/-}$mice (Supplemental Figure S4, A-D), again, a likely signifier of persistent infection.

We took particular note of relatively greater expansion among $\gamma \delta$ T cells in the $\mathrm{LN}$, because these cells were increased to a greater degree in IFN $\gamma \mathrm{RI}^{-1-} \mathrm{IL}^{2} 7 \mathrm{RA}^{-1-}$ mice than other T-cell populations; scLN $\gamma \delta$ T cells in IFN $\gamma \mathrm{RI}^{-/} \mathrm{IL} 17 \mathrm{RA}^{-1-}$ mice were expanded 24-fold over wild-type mice, compared with $<10$-fold expansions for $\mathrm{CD}^{+}$and $\mathrm{CD} 8^{+} \mathrm{T}$ cells. Cutaneous $\gamma \delta$ T cells have been shown to be critical sources of IL-17 in response to experimental S. aureus infection. ${ }^{5}$ Moreover, we found dramatic expansion of $\gamma \delta \mathrm{T}$ cells bearing signs of activation, effector, and memory differentiation in the scLNs of IFN $\gamma \mathrm{RI}^{-1-} \mathrm{IL} 17 \mathrm{RA}^{-1-}$ mice compared with controls, more so than in $\mathrm{CD} 4^{+} \alpha \beta$ T cells in these mice (Supplemental Figure $\mathrm{S} 4, \mathrm{E}-\mathrm{N}$ ), further supporting that the $\gamma \delta$ $\mathrm{T}$ cell lineage is more central to antistaphylococcal responses.

Defective expression of CXCL9 led us to examine the expression of its receptor, CXCR3, on lymphocytes in the scLNs, with particular regard for their activation and memory status by using the marker CD45RB (Figure 4, $\mathrm{E}-\mathrm{H})$. CXCR3 expression among $\mathrm{CD} 4^{+} \mathrm{T}$ cells was highest on $\mathrm{CD}_{45 \mathrm{RB}^{\mathrm{lo}}}$ cells, consistent with published reports (Figure 4, H-J). ${ }^{23-25}$ In contrast, among $\gamma \delta \mathrm{T}$ cells, $\mathrm{CD}_{45 \mathrm{RB}^{\text {hi }}}$ cells expressed CXCR3, whereas CD45RB ${ }^{\text {lo }}$ cells did not (Figure 4, F, K and L). These data indicated that in contrast to $\mathrm{CD} 4^{+} \mathrm{T}$ cells, which acquire CXCR3 expression on activation and memory differentiation, oral $\gamma \delta \mathrm{T}$ cells express CXCR3 in the naive state and lose it in the effector differentiation process.
Comparing CXCR3 expression across genotypes, we observed fewer $\mathrm{CD} 4{ }^{+} \mathrm{CD} 45 \mathrm{RB}^{\mathrm{lo}}$ and $\mathrm{TCR} \gamma \delta^{+} \mathrm{CD} 45 \mathrm{RB}^{\mathrm{hi}}$ $\mathrm{T}$ cells expressing CXCR3 in the scLNs of IFN $\gamma \mathrm{RI}^{-/-}$

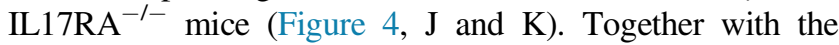
CXCL9 data, these findings suggested that CXCL9/CXCR3mediated recruitment of $\mathrm{CD}^{+}{ }^{+}$and $\gamma \delta \mathrm{T}$ cells to the affected perioral tissues may be disrupted (Figure 4, M-V). Absolute enumeration of these subsets, presented in Figure 4, M and $\mathrm{N}$, demonstrated that total numbers of $\mathrm{CD}^{+}$and $\gamma \delta \mathrm{T}$ cells were not elevated in IFN $\gamma \mathrm{RI}^{-1-} \mathrm{IL} 17 \mathrm{RA}^{-1-}$ mice, compared with $\mathrm{IL}_{17 R A}{ }^{-1-}$ single-knockout controls. Moreover, the frequency of $\gamma \delta \mathrm{T}$ cells infiltrating oral tissues was diminished in the IFN $\gamma \mathrm{RI}^{-1-} \mathrm{IL} 17 \mathrm{RA}^{-1-}$ strain, compared with the IL17RA $^{-1-}$ control (Figure 4V). From this pattern of recruitment, we conclude that in the absence of IFN$\gamma$-dependent CXCL9 signaling, recruitment of CD4 ${ }^{+}$and $\gamma \delta$ $\mathrm{T}$ cells to oral tissues is blunted in IFN $\gamma \mathrm{RI}^{-/-} \mathrm{IL} 17 \mathrm{RA}^{-1-}$ mice.

Cellular Mediators of Staphylococcal Lesions: Compromised Macrophage Function in the Absence of IFN- $\gamma$ Signaling

Examining the numerous canonical functions ascribed to IFN- $\gamma$ signaling, among the best studied involve the activation of antimicrobial effector immunity in macrophages and monocytes. ${ }^{26}$ In what is now termed classic or M1 activation of macrophages, IFN- $\gamma$ up-regulates nitric oxide production, antigen presentation and costimulation, and proinflammatory cytokine expression. ${ }^{27}$ In addition, chemokines downstream of both IFN- $\gamma$ and IL-17 signaling are known chemotactic factors for heterogeneous monocytic precursors, in association with divergent functionality among monocyte subpopulations. ${ }^{28}$

Numerically, we observed recruitment of all myeloid subsets: $\mathrm{F} 4 / 80^{+}$macrophages, Ly6C $\mathrm{C}^{\mathrm{hi}}$ inflammatory monocytes, and $\mathrm{Ly}_{6} \mathrm{C}^{\mathrm{lo}}$ resident monocytes into the affected perioral tissues of IFN $\gamma \mathrm{RI}^{-/-} \mathrm{IL} 17 \mathrm{RA}^{-/-}$mice (Figure 5, $\mathrm{A}-\mathrm{C}$ ). However, if these data were analyzed as a proportion of $\mathrm{CD} 11 \mathrm{~b}^{+} \mathrm{Ly} 6 \mathrm{G}^{-}$cells, to examine the relative balance of recruitment and differentiation of these subpopulations, several differences emerge. Proportions of $\mathrm{F} 4 / 80^{+}$macrophages were diminished in IFN $\gamma \mathrm{RI}^{-/-} \mathrm{IL} 17 \mathrm{RA}^{-1-}$ and IL17RA $^{-1-}$ mice (Figure 5D); similar defects were not observed in spleen (not shown), suggesting that IL-17 signaling contributes to monocyte-to-macrophage differentiation in situ. Moreover, the proportions of $\mathrm{Ly} 6 \mathrm{C}^{\mathrm{hi}} \mathrm{F} 4 / 80^{\text {lo }}$ inflammatory monocytes were diminished in IFN $\gamma \mathrm{RI}^{-/-}$ $\mathrm{IL}_{17 \mathrm{RA}^{-/-}}$and IFN $\gamma \mathrm{RI}^{-/-}$mice (Figure 5, E and G-J), and $\mathrm{Ly} 6 \mathrm{C}^{\text {lo }}$ resident monocytes were elevated in IFN $\gamma \mathrm{RI}^{-1-}$ IL17RA $^{-1-}$ mice (Figure 5, F-J). We have observed similar diminution of Ly6 $\mathrm{C}^{\text {hi }}$ monocytes and expansion of Ly6 $\mathrm{C}^{\text {lo }}$ monocytes in the draining LNs (not shown), but not spleen (not shown), indicating this population shift may be a specific recruitment defect in affected tissues. Taken together, these data indicate that IFN- $\gamma$ and IL-17 signaling 


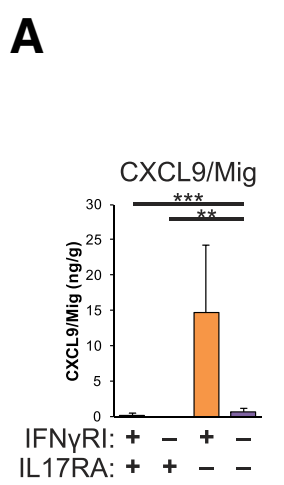

B

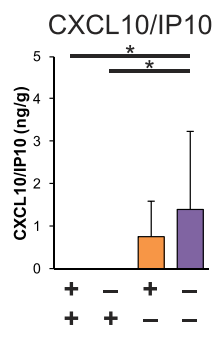

C

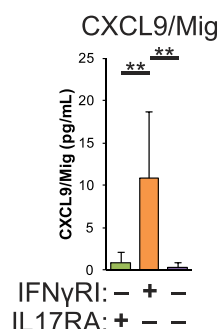

D

total scLNC

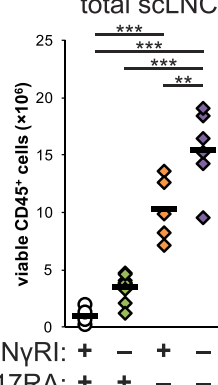

E

$\mathbf{F}$

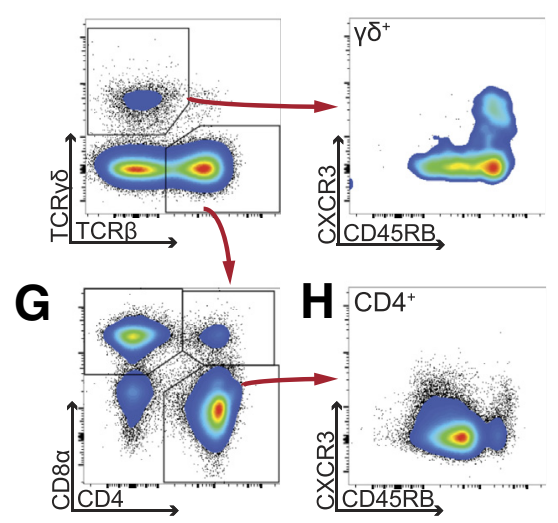

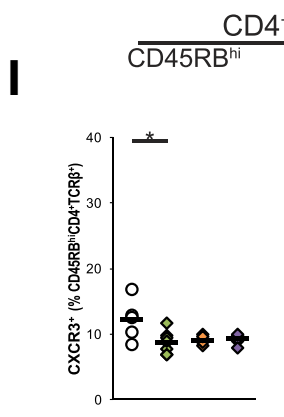

IFNyRI: + - + IL17RA: + + - -
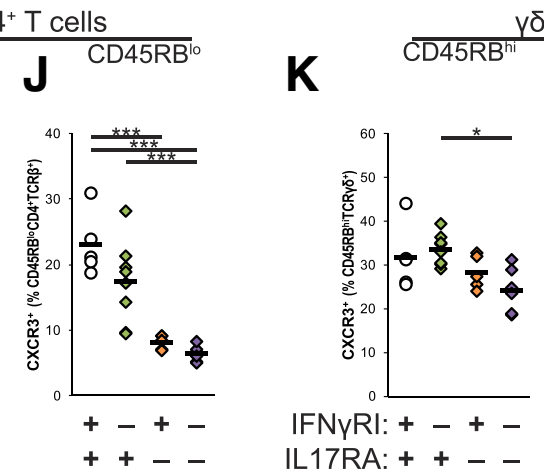
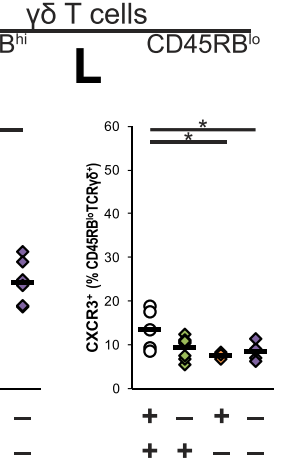

\section{M}

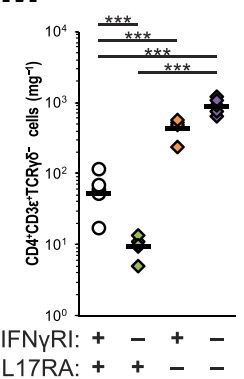

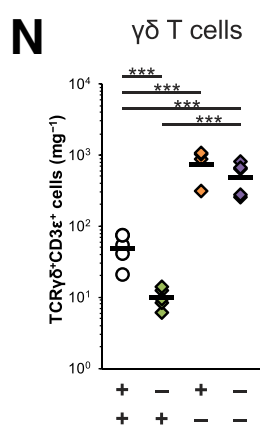
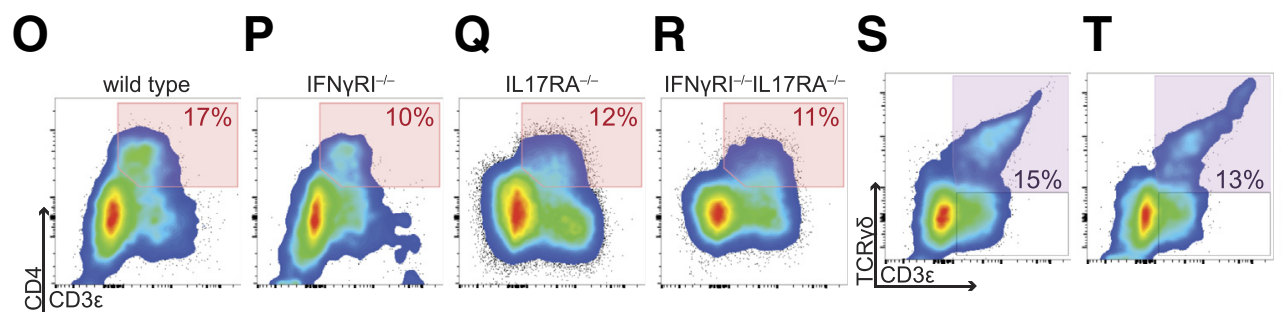

$\mathbf{U}$

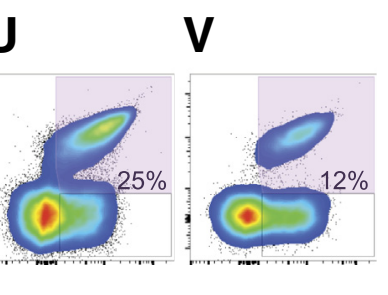

Figure 4 Lymphoid mediators of host defense to Staphylococcus aureus in IFN $\gamma \mathrm{RI}^{-/-}{ }^{-} \mathrm{IL}_{17 R A^{-/}}$mice and control strains. A-C: CXCL9 (A) and CXCL10 (B) interrogated by Linco 32-plex XMAP array from homogenates of oral tissues, normalized to sample weight; and supernatants from lymphocytes from the superficial cervical LN, restimulated with heat-killed S. aureus (C). D: Total counts of viable $\mathrm{CD}_{4} 5^{+}$cells from scLN. E-L: CXCR3 expression on scLN T-cell populations, as viable $C D 45^{+}$lymphocyte-gated cells from wild-type BALB/c mice in representative bivariate plots (E-H) and expressed as a proportion of parent populations, including total $\mathrm{CD} 4^{+} \mathrm{TCR} \beta^{+}$cells (I and $\mathbf{J}$ ) and $\gamma \delta^{+}$T cells ( $\mathbf{K}$ and $\mathbf{L}$ ). Red arrows denote gated populations. $\mathbf{M}$ and $\mathbf{N}$ : Total CD4 ${ }^{+}(\mathbf{M})$ and $\gamma \delta \mathrm{T}(\mathbf{N})$ cells infiltrating oral tissues, expressed as absolute numbers, normalized to sample weight. $\mathbf{0}-\mathbf{V}$ : Representative bivariate plots depict concatenates of each group, as a proportion of viable $\mathrm{CD}_{4} 5^{+}$lymphocytes. Regions shaded in red depict double-positive populations. Statistics are by one-way analysis of variance, followed by post hoc pairwise comparisons by Tukey-Kramer method. Statistically significant pairwise comparisons are denoted between relevant groups. ${ }^{*} P<0.05,{ }^{*} P \leq 0.01$, and ${ }^{* * *} P \leq 0.001$. IFN, interferon; scLN, superficial cervical lymph node; TCR, T-cell receptor.

collaborated in controlling the balance of differential monocyte recruitment to infected oral tissues.

We further examined the in situ expression of markers associated with classic M1 and alternative M2 activation of macrophages-CD54/intercellular adhesion molecule-1 (ICAM1) and the macrophage mannose receptor (CD206, $\mathrm{M} \varphi \mathrm{MR})$, respectively. $\mathrm{CD} 64^{+} \mathrm{F} 4 / 80^{+}$macrophages from the cheek were digested and stained for these markers. A greater proportion of macrophages in the oral tissues of GRAKO mice coexpressed ICAM1 and CD206/M $\varphi$ MR (Figure 5K).
Comparing single-positive macrophage subpopulations, a smaller proportion of macrophages expressed ICAM1, compared with IL17RA ${ }^{-1-}$ mice (Figure 5L), consistent with defective M1 activation. We also observed defective expression of an M2-like CD206/M $\varphi \mathrm{MR}^{+}$phenotype in IFN $\gamma \mathrm{RI}^{-/-}$ IL17RA ${ }^{-1-}$ and IL17RA ${ }^{-1-}$ mice (Figure $5 \mathrm{M}$ ), indicating that IFN- $\gamma$ and IL-17 signaling also colluded in driving polarization of macrophage effector phenotypes in oral tissues.

To experimentally address the role of macrophages in the collaboration of IFN- $\gamma$ and IL-17 signaling, we depleted 


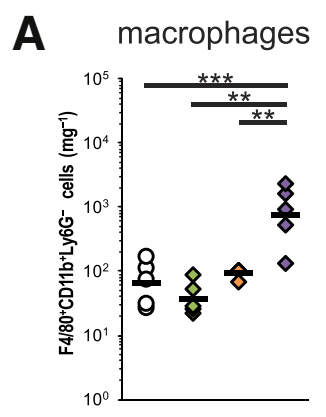

IFNyRI: + - + IL17RA: + + - -

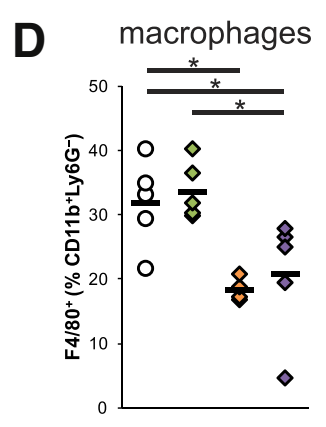

IFNyRI: + - + -

IL17RA: + + - -
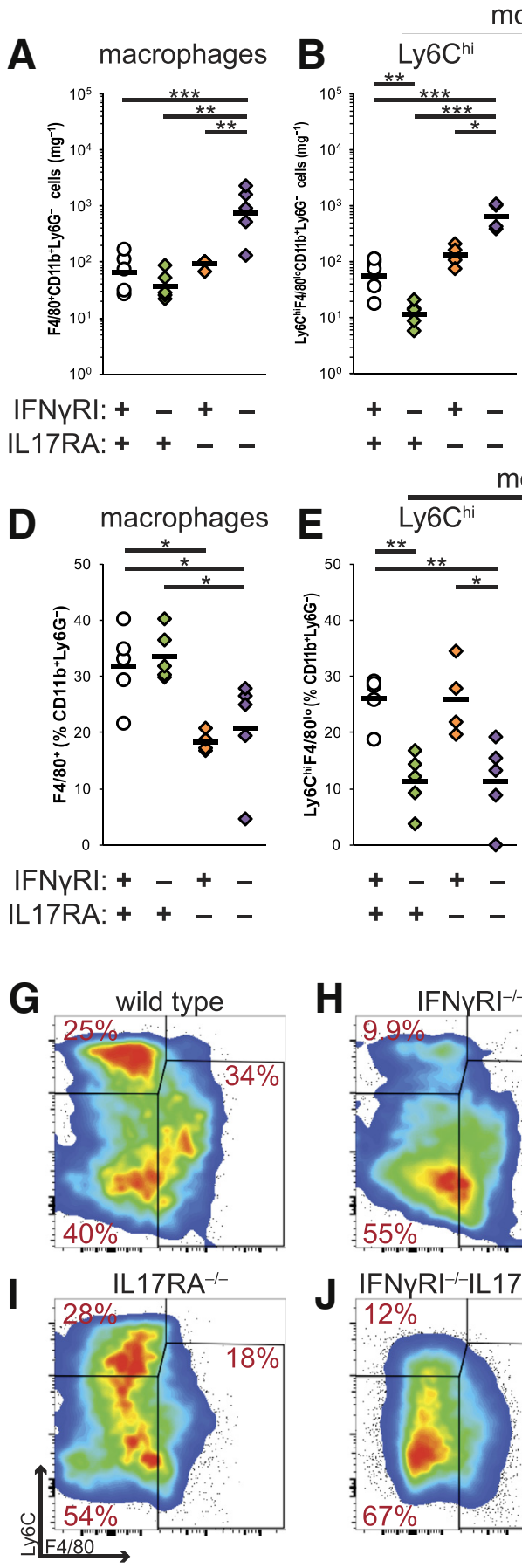

monocytes
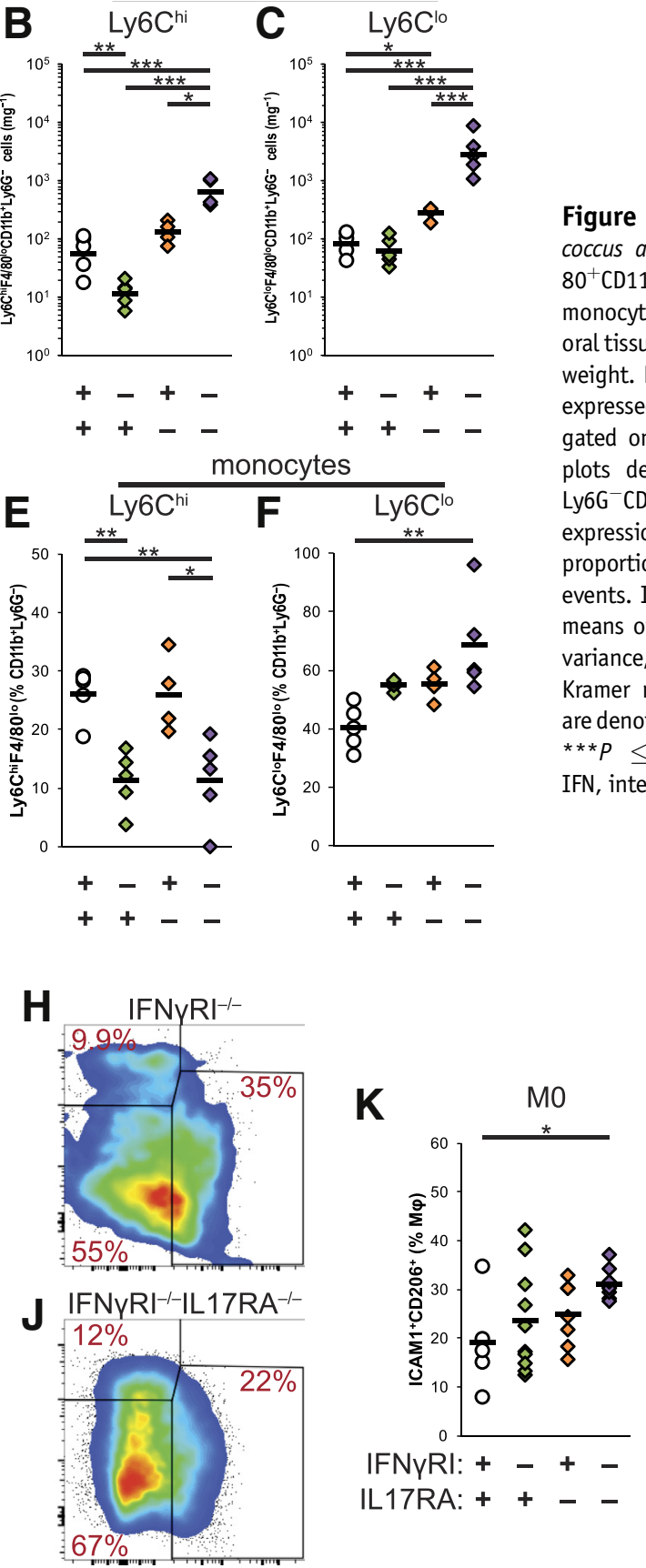

IFNyRI: + - + -

IL17RA: + + - -
Figure 5 Macrophage function in host defense to Staphylococcus aureus in IFN $\gamma \mathrm{RI}^{-/-}{ }^{-} \mathrm{IL}_{17 R A^{-/}}{ }^{-1}$ mice. A-C: Total F4/

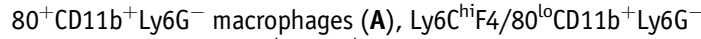
monocytes (B), and Ly6 $6 \mathrm{C}^{\mathrm{lo}} \mathrm{F} 4 / 80^{\mathrm{lo}} \mathrm{CD} 11 \mathrm{~b}^{+} \mathrm{Ly}_{6 \mathrm{G}^{-}}$monocytes (C) in oral tissues expressed as absolute numbers, normalized to sample weight. D-F: Proportions of oral macrophages and monocytes,

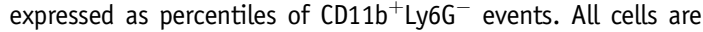
gated on viable $\mathrm{CD}_{4} 5^{+}$events. G-J: Representative bivariate plots depict concatenated groups gated on viable $C D 11 b^{+}$ Ly6G ${ }^{-} \mathrm{CD} 45^{+}$events. $\mathbf{K}-$ M: Macrophage polarization indicated by expression of CD54/ICAM1 and/or CD206/M MMR, expressed as a

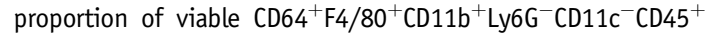
events. Individual mice are represented by diamonds or circles; means of groups by bars. Statistics are by one-way analysis of variance, followed by post hoc pairwise comparisons by TukeyKramer method. Statistically significant pairwise comparisons are denoted between relevant groups. ${ }^{*} P<0.05,{ }^{* *} P \leq 0.01$, and $* * * P \leq 0.001$. ICAM, intercellular adhesion molecule 1 ; IFN, interferon; M $\varphi M R$, macrophage mannose receptor. macrophages in vivo from IL17RA ${ }^{-1-}$ mice, proceeding from the hypothesis that the major function of IFN- $\gamma$ signaling in this system was to promote local recruitment and activation of the macrophage lineage in response to $S$. aureus. To accomplish this, we treated mice with liposomes loaded with lowdose clodronate, an approach that selectively targets cells of the MPS lineage for phagocytic uptake-mediated depletion (Figure 6, A and B). ${ }^{29}$ In both clodronate liposome and control groups, we observed progression of blepharitis lesions, consistent with the IL17RA ${ }^{-1-}$ background (Figure 6, C and E). However, in macrophage-depleted mice, we observed recapitulation of the oral lesions observed in IFN $\gamma \mathrm{RI}^{-/-}{ }^{\text {IL17RA }}{ }^{-1-}$ mice (Figure 6, D-I), splenomegaly (Figure $6 \mathrm{G}$ ), and outgrowth of S. aureus in the oral habitat (Figure $6 \mathbf{J}$ ). Histopathologic examination of oral tissues from clodronate liposome-treated mice confirmed the presence of Gram-positive cocci in these abscesses (Figure 6, K-P). These data strikingly corroborated our hypothesis that MPS-lineage cells were an important collaborator with IL-17-dependent defense to Staphylococcus in the oral mucosa. Moreover, these data were consistent with these MPS-lineage cells being critical signaling targets of IFN- $\gamma$. 

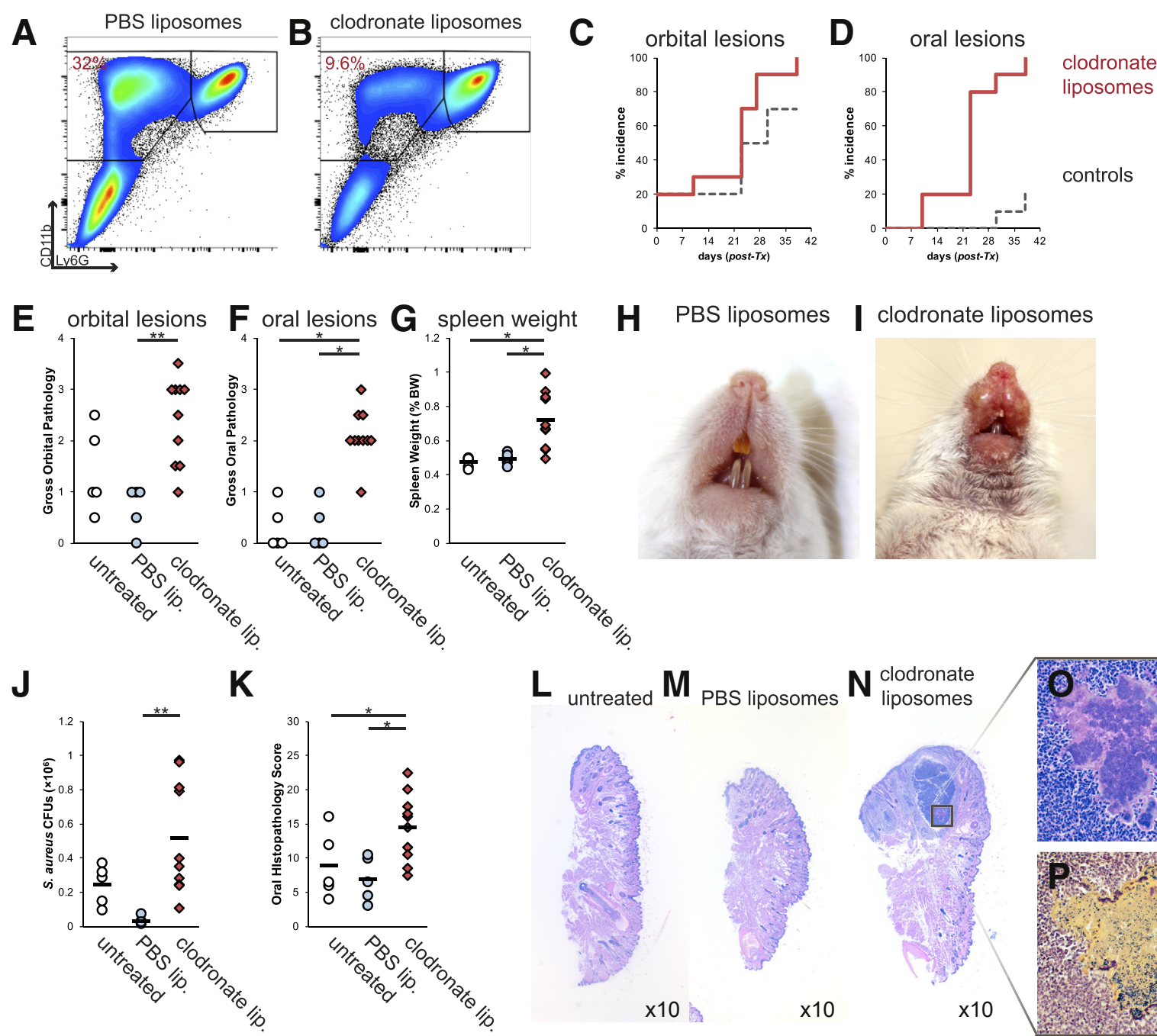

clodronate
liposomes
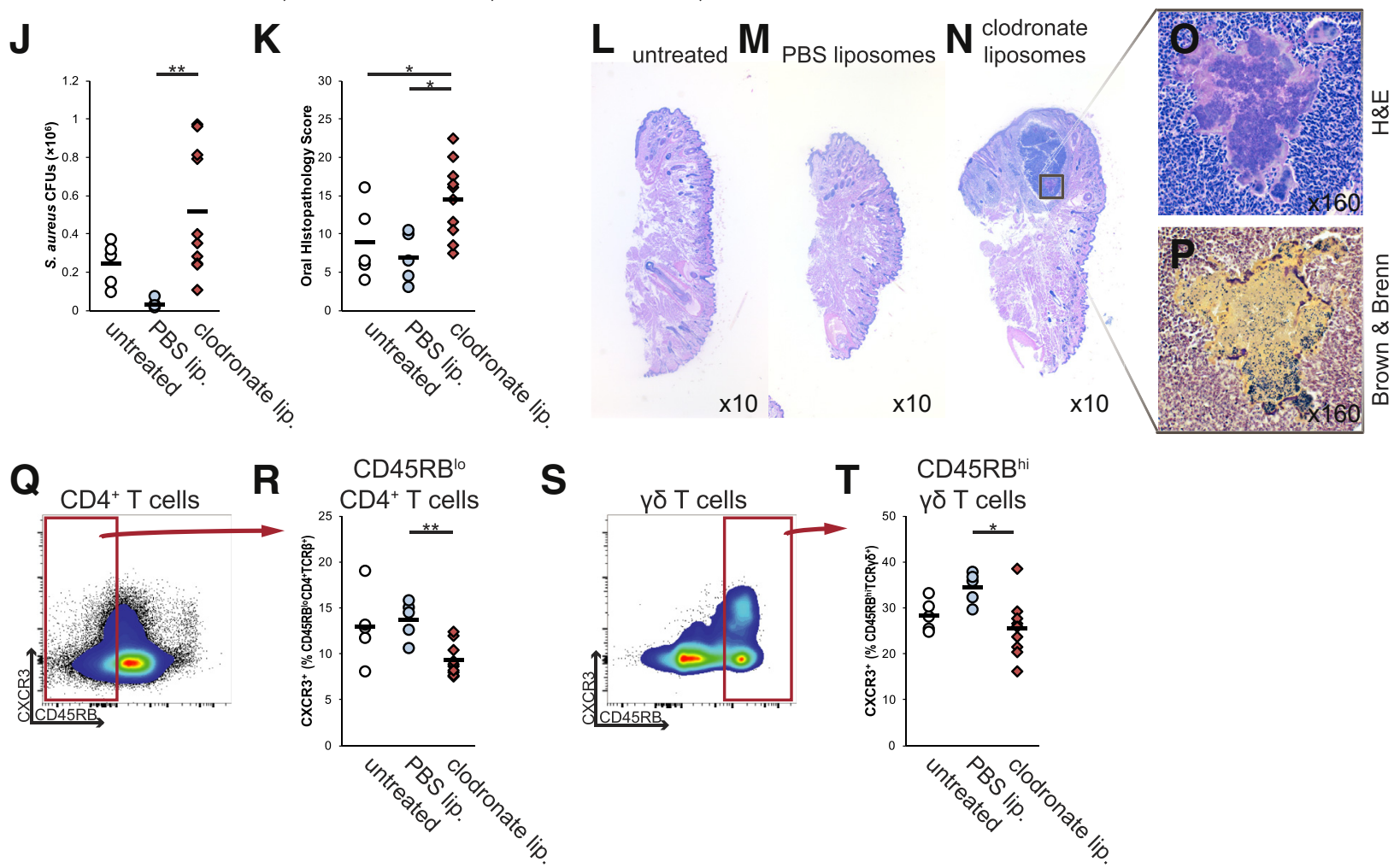

Figure 6 Macrophages are critical collaborators with IL-17-directed responses to Staphylococcus aureus in the oral mucosa. Data are representative of two independent experiments. A and B: Depletion of macrophages from oral tissues of IL17RA ${ }^{-1-}$ mice by treatment with clodronate-loaded liposomes; representative bivariate plots represent concatenated pools at day 10 of treatment. C and D: Progression of orbital (C) and oral (D) abscesses in IL17RA ${ }^{-/-}$mice depleted of macrophages by treatment with clodronate-loaded liposomes (red). Control IL17RA ${ }^{-1-}$ mice (gray) were untreated or administered PBS-loaded liposomes. E-G: Gross pathology of orbital (E) and oral abscesses (F), splenomegaly in IL17RA ${ }^{-1-}$ mice after 5 weeks of macrophage depletion (G). H and I: Representative gross oral pathologic lesions in IL17RA ${ }^{-1-}$ mice after 5 weeks of macrophage depletion. J: Oral colonization of macrophage-depleted IL17RA ${ }^{-/-}$mice and controls by S. aureus, represented as CFUs of S. aureus from oral swabs at week 5 of treatment. K-P: Histopathologic evaluation of oral abscesses in macrophage-depleted IL17RA ${ }^{-1-}$ mice $(\mathbf{K})$ and representative histopathology of oral lesions from control ( $\mathbf{L}$ and $\mathbf{M})$ or clodronate liposome-treated $(\mathbf{N}-\mathbf{P})$ mice. Boxed area in $\mathbf{N}$ is enlarged in $\mathbf{0}$ and $\mathbf{P}$. $\mathbf{Q}-\mathbf{T}$ : Expression of CXCR3 on $\mathrm{CD4}^{+}(\mathbf{Q}$ and $\mathbf{R})$ and $\gamma \delta \mathrm{T}$ cells $(\mathbf{S}$ and $\mathbf{T})$ in the $\mathrm{sCLN}$ of macrophage-depleted IL17RA ${ }^{-/-}$mice. Representative bivariate plots depict concatenates of groups, or individual mice. All cells are gated on viable $\mathrm{CD}_{4} 5^{+}$events. Individual mice are represented by diamonds or circles; means of groups by bars. Statistics are by one-way analysis of variance, followed by post hoc pairwise comparisons by Tukey-Kramer method. Statistically significant pairwise comparisons are denoted between relevant groups. $n=5$ untreated control IL17RA ${ }^{-/-}$mice; $n=5$ control IL17RA ${ }^{-1-}$ mice administered PBS-loaded liposomes (C and D). ${ }^{*} P<0.05$, ${ }^{* *} P \leq 0.01$. CFU, colony-forming unit; H\&E, hematoxylin and eosin; lip, liposome; PBS, phosphate-buffered saline; scLN, superficial cervical lymph node. 
We further examined the effector and memory differentiation of T cells in the draining LN. Although dendritic cells are thought to be major producers of CXCL9, this chemokine has also been reported from cell types in the monocyte/ macrophage lineage, particularly in the gastrointestinal mucosa. ${ }^{30-33}$ This led us to hypothesize that defective recruitment and activation of monocytes and macrophages may be responsible for the defect in CXCL9/CXCR3mediated recruitment of $\mathrm{T}$ cells described above. To address this, we assessed local $\mathrm{T}$ cell phenotypes from clodronateliposome-treated mice. Fewer $\mathrm{CD} 45 \mathrm{RB}^{\mathrm{lo}} \mathrm{CD} 4^{+}$memory $\mathrm{T}$ cells and $\mathrm{CD}^{2} 5 \mathrm{RB}^{\mathrm{hi}} \mathrm{TCR} \gamma \delta^{+}$cells in the scLNs of macrophage-depleted IL17RA ${ }^{-/-}$expressed CXCR3, compared with control phosphate-buffered saline-liposome-treated mice (Figure 6, Q-T), also phenotypically mimicking the T-cell recruitment defects observed in GRAKO mice. From this, we conclude that oral macrophages support recruitment of $\mathrm{T}$ cells to the infected oral mucosa.

\section{Discussion}

We describe here a novel, emergent model of spontaneous Staphylococcus aureus infection of the skin and oral mucosa in IFN $\gamma \mathrm{RI}^{-1-} \mathrm{IL} 17 \mathrm{RA}^{-1-}$ mice. Previously studied in isolation, this is the first demonstration to our knowledge that the archetypic effector cytokines of the Th1 and Th17 programs collaborate in mucosal host defense to $S$. aureus. ${ }^{5-7}$ Investigating these mechanisms in situ has revealed coordination of IL-17-driven neutrophils, and IFN- $\gamma$-dependent macrophages in controlling invasion and infection with $S$. aureus in the oral mucosa.

Our data support IL-17 signaling pathways and effector responses occupying a more central position in defense to $S$. aureus. In our animal facility at Johns Hopkins University, IL17RA ${ }^{-1-}$ mice develop low-level inflammation of the facial mucosa, including blepharitis, folliculitis, elevated serum IgG, localized lymphadenopathy, oral infiltration with neutrophils, $\mathrm{CD} 4^{+}$T-cell activation, maturation of dendritic and B cells (not shown), and oral expression of selected cytokines. Spontaneous mucocutaneous staphylococcal infections have been reported in some animal colonies deficient in IL-17 signaling. ${ }^{34,35}$ Because of no small part to environmental factors and background genetics, it is unclear how severe and replicable these other models are in direct comparison with IFN $\gamma \mathrm{RI}^{-1-} \mathrm{IL}_{17 \mathrm{RA}^{-1-}}$ mice. In addition to folliculitis, we observe some signs of limited abscess development in roughly one-quarter of IL17RA ${ }^{-/-}$ mice, but with less incidence and severity than in the GRAKO colony.

The IL17RA receptor subunit is thought to be a common signaling transducer for all members of the IL-17 family. ${ }^{36,37}$ Critical roles for IL-17A in defense to experimental skin infection with $S$. aureus have been described $^{5,38}$; however, we have not observed oral abscesses in our colony of IFN $\gamma^{-I-} \mathrm{IL}_{17 \mathrm{~A}^{-I-}}$ mice (data not shown), deficient in cytokine ligands rather than receptors, underscoring that IL-17A is not the critical IL-17 family member in this mucocutaneous disease process. Candidate alternative IL-17 family members include IL-17C and IL-17F. ${ }^{35,39}$

Part of the original description of Th17 cells as a unique and separate lineage underscored that $\mathrm{IL}-23$, rather than IL-12, signaling was critical for the differentiation of these cells. ${ }^{40}$ Moreover, Th1 programing suppressed the differentiation of Th17 cells, in a manner analogous to the mutual countersuppression of the Th1 and Th2 lineages. ${ }^{41,42}$ It has since become clearer that there exist more complex relations between the Th1 and Th17 programs. Coexpression of IFN- $\gamma$ and IL-17 had been reported in some of the earliest characterizations of the Th17 program. ${ }^{43-45}$ The development of fluorescent reporter strains for tracking Th17 cell fating further demonstrated clear plasticity among these lineages; a sizable fraction of Th17 cells convert into IFN- $\gamma$-producing cells in pathogenic circumstances, including infection and autoimmune disease. ${ }^{46}$ Moreover, although IL-17 production remains archetypally definitive for the Th17 lineage, it is also clear that other inflammatory cytokines can be elicited from Th17 cells, including IL-6, IL-17F, IL-22, and granulocytemacrophage CSF. ${ }^{47,48}$

IL-17-driven neutrophilic responses have been reported to be a hallmark of host defense to an experimentally induced model of $S$. aureus infection in cutaneous tissues. ${ }^{4}$ The cytokines IL-1 $\beta$ and IL-17A are critically important in establishing a positive feedback conduit between responding neutrophils and T cells in controlling S. aureus. ${ }^{5,6} \mathrm{De}-$ fects in components of these signaling pathways, their upstream triggers, and downstream effectors are associated with susceptibility to $S$. aureus. Such critical pathways include myeloid differentiation primary response gene 88 and IL-1 receptor-associated kinase-4, ${ }^{49-51}$ as well as defects in granulopoiesis. ${ }^{52,53} \mathrm{We}$ found highly neutrophilic infiltration into the oral tissues of IFN $\gamma \mathrm{RI}^{-/-} \mathrm{IL} 17 \mathrm{RA}^{-1-}$ mice, indicating there was no defect in neutrophil recruitment in these mice. Instead, we interrogated tissue MPO, as an in situ surrogate marker for neutrophil function in vivo, finding diminished estimated per-cell levels of tissue MPO. Additional microbicidal functions were not interrogated, retaining the possibility that other neutrophil antimicrobial pathways were unaffected. ${ }^{54}$ In vitro, we did not observe defective $S$. aureus killing by IFN $\gamma \mathrm{RI}^{-1-} \mathrm{IL}_{17 \mathrm{RA}^{-1-}}$ neutrophils, emphasizing the likelihood of an additional cellular partner being required to observe defective antimicrobial function in IFN $\gamma \mathrm{RI}^{-/}{ }^{-1}$ IL17RA ${ }^{-/-}$mice.

Altogether, our findings are consistent with these reports. In our mouse cohorts, IFN- $\gamma$ pathways seemed to be lesser contributors than those mediated by IL-17 in the disease of IFN $\gamma \mathrm{RI}^{-1-}$ IL17RA ${ }^{-1-}$ mice; IFN $\gamma \mathrm{RI}^{-1-}$ control mice appeared more phenotypically normal than IFN $\gamma \mathrm{RI}^{-1-}$ IL17RA $^{-1-}$ or IL17RA ${ }^{-1-}$ mice. From this, we conclude that IL-17, rather than IFN- $\gamma$, was critical for initial barrier 
defenses. However, an IFN- $\gamma$-dependent mechanism was important as a collaborative secondary defense in the failure of IL-17-dependent protection. This contribution of IFN- $\gamma$ to this collaborative mechanism was of great interest, especially given disagreement as to the role of IFN- $\gamma$ in defense to $S$. aureus. Blockade of IFN- $\gamma$ protected animals from death after high-dose systemic infection with $S$. aureus. $^{7}$ Similarly, survival of IFN $\gamma^{-l-}$ or IFN $\gamma \mathrm{RI}^{-/-}$mice was improved after i.v. S. aureus infection. ${ }^{8,10}$ From these data, these researchers ascribed pathogenic roles for IFN- $\gamma$ in response to $S$. aureus; although it should be noted that these findings precede the discovery of the Th17 lineage.

Of the numerous pleiotropic effects driven by IFN- $\gamma$, among the best studied include the classic activation of macrophages in which IFN- $\gamma$ drives a potent antimicrobial program, including nitric oxide and superoxide production, as well as lysosomal maturation. ${ }^{27,55}$ Bactericidal macrophage functions have been investigated in defense to $S$. aureus, with particular regard for the potential of $S$. aureus to persist in macrophage endocytic compartments. ${ }^{56-59}$ The effectiveness of antistaphylococcal macrophage bactericidal activity in vitro was enhanced by IFN- $\gamma$ signaling. ${ }^{60}$ These data point to a role for IFN- $\gamma$-dependent macrophage differentiation in defense to $S$. aureus. To test this hypothesis, we depleted monocytes and macrophages in vivo from IL17RA ${ }^{-1-}$ mice using clodronate-loaded liposomes. ${ }^{29}$ This treatment elicited oral abscesses, recapitulating the disease of GRAKO mice, which has not been true of other models in which we have applied this strategy of macrophage depletion. ${ }^{61}$ From this, we conclude that macrophages are an important collaborator with IL-17-dependent defenses to S. aureus.

In addition to effects on macrophages, a role has been reported for IFN- $\gamma$ in amnestic recall responses to S. aureus. $^{9}$ Our data indicate that IFN- $\gamma$ was critically important in driving CXCL9 expression in response to $S$. aureus in infected oral tissues. CXCL9 is among several chemokines expressed under the control of IFN$\gamma \cdot{ }^{62,63}$ Among these, CXCL9 was the only analyte for which we observed defective expression in the GRAKO strain. CXCL9 expression has been reported in response to pulmonary infection with $S$. aureus. ${ }^{64}$ The cognate receptor for CXCL9, CXCR3, is expressed on T cells undergoing memory and effector differentiation. ${ }^{65,66}$ In addition to diminished expression of CXCR 3 on $\mathrm{T}$ cells, we further found limited recruitment of $\mathrm{T}$ cells to oral tissues in GRAKO mice. Together, these data indicate that in response to $S$. aureus, IFN- $\gamma$ directed CXCL9 expression, which in turn drove recruitment of T cells to affected oral tissues. Furthermore, we found that macrophage depletion mimicked the defects in recruitment of $\mathrm{CXCR}^{+}{ }^{+} \mathrm{T}$ cells observed in GRAKO mice. From this, we further conclude that IFN- $\gamma$-driven M1 polarization supports a positive feedback circuit between macrophages and responding $\mathrm{T}$ cells through CXCL9/CXCR3 signaling.
In this data set, we also observed some signs of Th2 deviation, including elevated local production of IL-4 and CCL11/eotaxin, and elevated serum IgE. However, we did not observe substantial elevations of tissue infiltration with eosinophils or cells of the basophil/mast cell lineage. Moreover, intracellular staining did not demonstrate increased frequencies of IL-4-producing T cells in the LNs of affected IFN $\gamma^{-1-}$ IL17 $\mathrm{A}^{-1-}$ mice (not shown). We take these data to indicate that IFN $\gamma \mathrm{RI}^{-1-}$ IL17RA ${ }^{-1-}$ mice do not undergo a canonical Th2 deviation at a clonal level, that elevated IL-4 and CCL11 levels are indicative of the ongoing response to chronic infection, at a scale comparable with numerous other inflammatory cytokines and chemokines. Put another way, there is not sufficient evidence to support Th2 deviation being the sole or primary instigator of disease in $\mathrm{IFN} \gamma^{-1-} \mathrm{IL} 17 \mathrm{~A}^{-1-}$ mice. In experimental infection models, roles for Th2 cytokines have been proposed as contributors to staphylococcal clearance. ${ }^{8}$

Roles for both IFN- $\gamma$ and IL-17 signaling, and associated pathways, have been reported in human staphylococcal infections. In patients, inflammatory and immunodeficiency disorders are important factors determining host susceptibility to staphylococcal infection. ${ }^{2}$ Among the discrete immunodeficiencies associated with staphylococcal opportunism, hyper IgE syndrome (HIES) represents clusters of mutations in the inflammatory cytokine signal transducer and transcription factor STAT3; defective IL-17-centered immunity underpins much of the susceptibility to infection in HIES. ${ }^{67-70}$ Several groups have reported defective IFN- $\gamma$ production capacity in peripheral blood mononuclear cells from HIES patients, with particular regard for explicating the elevations of $\mathrm{IgE}$ production that are pathognomic for the disease. $^{71-73}$ Here, we report that IFN $\gamma \mathrm{RI}^{-1-} \mathrm{IL}_{17 \mathrm{RA}^{-1-}}$ mice phenocopy the pathognomic laboratory finding of drastically elevated serum $\operatorname{IgE}$ in HIES patients; IFN $\gamma \mathrm{RI}^{-1-} \mathrm{IL} 17 \mathrm{RA}^{-1-}$ mice had on average $>100$ times the levels of circulating IgE, in comparison with wild-type control mice. From these data, we conclude the disease of IFN $\gamma \mathrm{RI}^{-/-} \mathrm{IL}_{17 \mathrm{RA}}{ }^{-1-}$ mice recapitulates the susceptibility of HIES patients to staphylococcal infection.

From our findings, we propose the following model: IL-17 signaling is required for initial barrier defense to $S$. aureus through controlling local neutrophil recruitment in a manner that feeds back to IL-17 production by $\mathrm{CD}^{+}$and $\gamma \delta \mathrm{T}$ cells via IL- $1 \beta$ production. In the oral mucosa, this IL- 17 family member is not IL-17A. Disruption of this circuit enables opportunistic staphylococcal colonization of the oral mucosa. IFN- $\gamma$-dependent mechanisms serve as a secondary defense, enabling local macrophage differentiation and activation, as well as recruiting activated or memory lymphocytes via CXCL9/Mig. Moreover, these IFN- $\gamma-$ mediated effects require collaborative synergy with IL-17-driven neutrophilic defenses for maximal effectiveness. Collaborative recognition of neutrophil extracellular traps by macrophages have been demonstrated to be important in clearance of $S$. aureus in vitro. ${ }^{74}$ Moreover, IFN- $\gamma$-driven macrophages form a 
positive feedback circuit, assisting in the recruitment of T cells through CXCL9 expression. Other functional defects in the host response to $S$. aureus seem likely to also be occurring, and need not be exclusive with the mechanisms proposed here.

\section{Acknowledgments}

We thank Amgen and Dr. Jay Kolls (University of Pittsburgh) for their generous provision of IL17RA ${ }^{-l-}$ BALB/c founder mice; Cory Brayton and Zachary Freeman (Johns Hopkins University School of Medicine Phenotyping Core) for assistance with initial characterization of IFN $\gamma \mathrm{RI}^{-/}$ IL17RA $^{-1-}$ mice; Xiaoling Zhang (Johns Hopkins University School of Medicine Analytic Cytometry Core); Shanna Ludwig for expert assistance with quantitative microbiology; the editors for helpful suggestions and formatting the figures; and Norman J. Barker (Pathology Photography and Graphic Arts Laboratory, Johns Hopkins University School of Medicine) for expert assistance with photomicrography.

\section{Supplemental Data}

Supplemental material for this article can be found at http://dx.doi.org/10.1016/j.ajpath.2016.07.001.

\section{References}

1. Barin JG, Baldeviano GC, Talor MV, Wu L, Ong S, Fairweather D, Bedja D, Stickel NR, Fontes JA, Cardamone AB, Zheng D, Gabrielson KL, Rose NR, Cihakova D: Fatal eosinophilic myocarditis develops in the absence of IFN-gamma and IL-17A. J Immunol 2013, 191:4038-4047

2. Lowy FD: Staphylococcus aureus infections. N Engl J Med 1998, 339:520-532

3. Tong SY, Davis JS, Eichenberger E, Holland TL, Fowler VG Jr: Staphylococcus aureus infections: epidemiology, pathophysiology, clinical manifestations, and management. Clin Microbiol Rev 2015, 28:603-661

4. Miller LS, Cho JS: Immunity against Staphylococcus aureus cutaneous infections. Nat Rev Immunol 2011, 11:505-518

5. Cho JS, Pietras EM, Garcia NC, Ramos RI, Farzam DM, Monroe HR, Magorien JE, Blauvelt A, Kolls JK, Cheung AL, Cheng G, Modlin RL, Miller LS: IL-17 is essential for host defense against cutaneous Staphylococcus aureus infection in mice. J Clin Invest 2010, 120:1762-1773

6. Cho JS, Guo Y, Ramos RI, Hebroni F, Plaisier SB, Xuan C, Granick JL, Matsushima H, Takashima A, Iwakura Y, Cheung AL, Cheng G, Lee DJ, Simon SI, Miller LS: Neutrophil-derived IL-1beta is sufficient for abscess formation in immunity against Staphylococcus aureus in mice. PLoS Pathog 2012, 8:e1003047

7. Nakane A, Okamoto M, Asano M, Kohanawa M, Minagawa T: Endogenous gamma interferon, tumor necrosis factor, and interleukin-6 in Staphylococcus aureus infection in mice. Infect Immun 1995, 63:1165-1172

8. Sasaki S, Nishikawa S, Miura T, Mizuki M, Yamada K, Madarame H, Tagawa YI, Iwakura Y, Nakane A: Interleukin-4 and interleukin-10 are involved in host resistance to Staphylococcus aureus infection through regulation of gamma interferon. Infect Immun 2000, 68:2424-2430
9. Sasaki S, Tagawa Y, Iwakura Y, Nakane A: The role of gamma interferon in acquired host resistance against Staphylococcus aureus infection in mice. FEMS Immunol Med Microbiol 2006, 46:367-374

10. Zhao YX, Tarkowski A: Impact of interferon-gamma receptor deficiency on experimental Staphylococcus aureus septicemia and arthritis. J Immunol 1995, 155:5736-5742

11. Committee for the Update of the Guide for the Care and Use of Laboratory Animals; National Research Council. Edited by Guide for the Care and Use of Laboratory Animals: Eighth Edition. Washington, DC: National Academies Press, 2011

12. Davis MF, Baron P, Price LB, Williams DL, Jeyaseelan S, Hambleton IR, Diette GB, Breysse PN, McCormack MC: Dry collection and culture methods for recovery of methicillin-susceptible and methicillin-resistant Staphylococcus aureus strains from indoor home environments. Appl Environ Microbiol 2012, 78:2474-2476

13. Garcia-Alvarez L, Holden MT, Lindsay H, Webb CR, Brown DF, Curran MD, Walpole E, Brooks K, Pickard DJ, Teale C, Parkhill J, Bentley SD, Edwards GF, Girvan EK, Kearns AM, Pichon B, Hill RL, Larsen AR, Skov RL, Peacock SJ, Maskell DJ, Holmes MA: Methicillin-resistant Staphylococcus aureus with a novel mecA homologue in human and bovine populations in the UK and Denmark: a descriptive study. Lancet Infect Dis 2011, 11:595-603

14. Shopsin B, Gomez M, Montgomery SO, Smith DH, Waddington M, Dodge DE, Bost DA, Riehman M, Naidich S, Kreiswirth BN: Evaluation of protein A gene polymorphic region DNA sequencing for typing of Staphylococcus aureus strains. J Clin Microbiol 1999, $37: 3556-3563$

15. Sasaki T, Tsubakishita S, Tanaka Y, Sakusabe A, Ohtsuka M, Hirotaki S, Kawakami T, Fukata T, Hiramatsu K: Multiplex-PCR method for species identification of coagulase-positive staphylococci. J Clin Microbiol 2010, 48:765-769

16. Zhang K, McClure JA, Elsayed S, Louie T, Conly JM: Novel multiplex PCR assay for simultaneous identification of communityassociated methicillin-resistant Staphylococcus aureus strains USA300 and USA400 and detection of mecA and Panton-Valentine leukocidin genes, with discrimination of Staphylococcus aureus from coagulase-negative staphylococci. J Clin Microbiol 2008, 46: $1118-1122$

17. Poyart C, Quesne G, Boumaila C, Trieu-Cuot P: Rapid and accurate species-level identification of coagulase-negative staphylococci by using the sodA gene as a target. J Clin Microbiol 2001, 39: 4296-4301

18. Puel A, Cypowyj S, Bustamante J, Wright JF, Liu L, Lim HK Migaud M, Israel L, Chrabieh M, Audry M, Gumbleton M, Toulon A, Bodemer C, El-Baghdadi J, Whitters M, Paradis T, Brooks J, Collins M, Wolfman NM, Al-Muhsen S, Galicchio M, Abel L, Picard C, Casanova JL: Chronic mucocutaneous candidiasis in humans with inborn errors of interleukin-17 immunity. Science 2011, 332:65-68

19. Boisson B, Wang C, Pedergnana V, Wu L, Cypowyj S, Rybojad M, Belkadi A, Picard C, Abel L, Fieschi C, Puel A, Li X, Casanova JL: An ACT1 mutation selectively abolishes interleukin-17 responses in humans with chronic mucocutaneous candidiasis. Immunity 2013, 39: 676-686

20. Bae IG, Tonthat GT, Stryjewski ME, Rude TH, Reilly LF, Barriere SL, Genter FC, Corey GR, Fowler VG Jr: Presence of genes encoding the panton-valentine leukocidin exotoxin is not the primary determinant of outcome in patients with complicated skin and skin structure infections due to methicillin-resistant Staphylococcus aureus: results of a multinational trial. J Clin Microbiol 2009, 47: $3952-3957$

21. Holtfreter S, Radcliff FJ, Grumann D, Read H, Johnson S, Monecke S, Ritchie S, Clow F, Goerke C, Broker BM, Fraser JD, Wiles S: Characterization of a mouse-adapted Staphylococcus aureus strain. PLoS One 2013, 8:e71142

22. Kim MH, Granick JL, Kwok C, Walker NJ, Borjesson DL, Curry FR, Miller LS, Simon SI: Neutrophil survival and c-kit(+)-progenitor 
proliferation in Staphylococcus aureus-infected skin wounds promote resolution. Blood 2011, 117:3343-3352

23. Mohan K, Cordeiro E, Vaci M, McMaster C, Issekutz TB: CXCR3 is required for migration to dermal inflammation by normal and in vivo activated T cells: differential requirements by CD4 and CD8 memory subsets. Eur J Immunol 2005, 35:1702-1711

24. Rivino L, Messi M, Jarrossay D, Lanzavecchia A, Sallusto F, Geginat J: Chemokine receptor expression identifies Pre-T helper (Th)1, Pre-Th2, and nonpolarized cells among human CD4+ central memory T cells. J Exp Med 2004, 200:725-735

25. Song K, Rabin RL, Hill BJ, De Rosa SC, Perfetto SP, Zhang HH, Foley JF, Reiner JS, Liu J, Mattapallil JJ, Douek DC, Roederer M, Farber JM: Characterization of subsets of CD4+ memory T cells reveals early branched pathways of $\mathrm{T}$ cell differentiation in humans. Proc Natl Acad Sci U S A 2005, 102:7916-7921

26. Mosser DM: The many faces of macrophage activation. J Leukoc Biol 2003, 73:209-212

27. Martinez FO, Helming L, Gordon S: Alternative activation of macrophages: an immunologic functional perspective. Annu Rev Immunol 2009, 27:451-483

28. Geissmann F, Jung S, Littman DR: Blood monocytes consist of two principal subsets with distinct migratory properties. Immunity 2003, 19:71-82

29. van Rooijen N, van Kesteren-Hendrikx E: "In vivo" depletion of macrophages by liposome-mediated "suicide". Methods Enzymol 2003, 373:3-16

30. Liao F, Rabin RL, Yannelli JR, Koniaris LG, Vanguri P, Farber JM: Human Mig chemokine: biochemical and functional characterization. J Exp Med 1995, 182:1301-1314

31. Teruya-Feldstein J, Jaffe ES, Burd PR, Kanegane H, Kingma DW, Wilson WH, Longo DL, Tosato G: The role of Mig, the monokine induced by interferon-gamma, and IP-10, the interferon-gammainducible protein-10, in tissue necrosis and vascular damage associated with Epstein-Barr virus-positive lymphoproliferative disease. Blood 1997, 90:4099-4105

32. Eck M, Schmausser B, Scheller K, Toksoy A, Kraus M, Menzel T, Muller-Hermelink HK, Gillitzer R: CXC chemokines Gro(alpha)/IL-8 and IP-10/MIG in Helicobacter pylori gastritis. Clin Exp Immunol 2000, 122:192-199

33. Ciccia F, Alessandro R, Rizzo A, Accardo-Palumbo A, Raimondo S, Raiata F, Guggino G, Giardina A, De Leo G, Sireci G, Triolo G: Macrophage phenotype in the subclinical gut inflammation of patients with ankylosing spondylitis. Rheumatology 2014, 53:104-113

34. Schwarzenberger P, Kolls JK: Interleukin 17: an example for gene therapy as a tool to study cytokine mediated regulation of hematopoiesis. J Cell Biochem Suppl 2002, 38:88-95

35. Ishigame H, Kakuta S, Nagai T, Kadoki M, Nambu A, Komiyama Y, Fujikado N, Tanahashi Y, Akitsu A, Kotaki H, Sudo K, Nakae S, Sasakawa C, Iwakura Y: Differential roles of interleukin-17A and $-17 \mathrm{~F}$ in host defense against mucoepithelial bacterial infection and allergic responses. Immunity 2009, 30:108-119

36. Gaffen SL, Jain R, Garg AV, Cua DJ: The IL-23-IL-17 immune axis: from mechanisms to therapeutic testing. Nat Rev Immunol 2014, 14 : 585-600

37. Gaffen SL: Structure and signalling in the IL-17 receptor family. Nat Rev Immunol 2009, 9:556-567

38. Lin L, Ibrahim AS, Xu X, Farber JM, Avanesian V, Baquir B, Fu Y, French SW, Edwards JE Jr, Spellberg B: Th1-Th17 cells mediate protective adaptive immunity against Staphylococcus aureus and Candida albicans infection in mice. PLoS Pathog 2009, 5:e1000703

39. Conti HR, Whibley N, Coleman BM, Garg AV, Jaycox JR, Gaffen SL: Signaling through IL-17C/IL-17RE is dispensable for immunity to systemic, oral and cutaneous candidiasis. PLoS One 2015, 10:e122807

40. Bettelli E, Carrier Y, Gao W, Korn T, Strom TB, Oukka M, Weiner HL, Kuchroo VK: Reciprocal developmental pathways for the generation of pathogenic effector TH17 and regulatory T cells. Nature 2006, 441:235-238
41. Harrington LE, Hatton RD, Mangan PR, Turner H, Murphy TL, Murphy KM, Weaver CT: Interleukin 17-producing CD4+ effector T cells develop via a lineage distinct from the $\mathrm{T}$ helper type 1 and 2 lineages. Nat Immunol 2005, 6:1123-1132

42. Damsker JM, Hansen AM, Caspi RR: Th1 and Th17 cells: adversaries and collaborators. Ann N Y Acad Sci 2010, 1183:211-221

43. Veldhoen M, Hocking RJ, Atkins CJ, Locksley RM, Stockinger B: TGFbeta in the context of an inflammatory cytokine milieu supports de novo differentiation of IL-17-producing T cells. Immunity 2006, 24:179-189

44. Lee YK, Mukasa R, Hatton RD, Weaver CT: Developmental plasticity of Th17 and Treg cells. Curr Opin Immunol 2009, 21:274-280

45. Kebir H, Ifergan I, Alvarez JI, Bernard M, Poirier J, Arbour N, Duquette P, Prat A: Preferential recruitment of interferon-gamma-expressing TH17 cells in multiple sclerosis. Ann Neurol 2009, 66:390-402

46. Hirota K, Duarte JH, Veldhoen M, Hornsby E, Li Y, Cua DJ, Ahlfors H, Wilhelm C, Tolaini M, Menzel U, Garefalaki A, Potocnik AJ, Stockinger B: Fate mapping of IL-17-producing T cells in inflammatory responses. Nat Immunol 2011, 12:255-263

47. Sallusto F, Zielinski CE, Lanzavecchia A: Human Th17 subsets. Eur J Immunol 2012, 42:2215-2220

48. Peters A, Lee Y, Kuchroo VK: The many faces of Th17 cells. Curr Opin Immunol 2011, 23:702-706

49. Picard C, Puel A, Bonnet M, Ku CL, Bustamante J, Yang K, Soudais C, Dupuis S, Feinberg J, Fieschi C, Elbim C, Hitchcock R, Lammas D, Davies G, Al-Ghonaium A, Al-Rayes H, Al-Jumaah S, Al-Hajjar S, Al-Mohsen IZ, Frayha HH, Rucker R, Hawn TR, Aderem A, Tufenkeji H, Haraguchi S, Day NK, Good RA, GougerotPocidalo MA, Ozinsky A, Casanova JL: Pyogenic bacterial infections in humans with IRAK-4 deficiency. Science 2003, 299:2076-2079

50. Picard C, von Bernuth H, Ghandil P, Chrabieh M, Levy O, Arkwright PD, et al: Clinical features and outcome of patients with IRAK-4 and MyD88 deficiency. Medicine 2010, 89:403-425

51. von Bernuth H, Picard C, Jin Z, Pankla R, Xiao H, Ku CL, et al: Pyogenic bacterial infections in humans with MyD88 deficiency. Science 2008, 321:691-696

52. Gonzalez-Barca E, Carratala J, Mykietiuk A, Fernandez-Sevilla A, Gudiol F: Predisposing factors and outcome of Staphylococcus aureus bacteremia in neutropenic patients with cancer. Eur J Clin Microbiol Infect Dis 2001, 20:117-119

53. Andrews T, Sullivan KE: Infections in patients with inherited defects in phagocytic function. Clin Microbiol Rev 2003, 16:597-621

54. Winterbourn CC, Kettle AJ, Hampton MB: Reactive Oxygen Species and Neutrophil Function. Annu Rev Biochem 2016, 85:765-792

55. Gordon S, Taylor PR: Monocyte and macrophage heterogeneity. Nat Rev Immunol 2005, 5:953-964

56. Hamza T, Li B: Differential responses of osteoblasts and macrophages upon Staphylococcus aureus infection. BMC Microbiol 2014, 14:207

57. Dey S, Bishayi B: Killing of Staphylococcus aureus in murine macrophages by chloroquine used alone and in combination with ciprofloxacin or azithromycin. J Inflamm Res 2015, 8:29-47

58. Das D, Bishayi B: Staphylococcal catalase protects intracellularly survived bacteria by destroying $\mathrm{H} 2 \mathrm{O} 2$ produced by the murine peritoneal macrophages. Microb Pathog 2009, 47:57-67

59. Das D, Bishayi B: Contribution of Catalase and Superoxide Dismutase to the Intracellular Survival of Clinical Isolates of Staphylococcus aureus in Murine Macrophages. Indian J Microbiol 2010, 50: 375-384

60. Smith RP, Baltch AL, Ritz WJ, Michelsen PB, Bopp LH: IFN-gamma enhances killing of methicillin-resistant Staphylococcus aureus by human monocytes more effectively than GM-CSF in the presence of daptomycin and other antibiotics. Cytokine 2010, 51:274-277

61. Wu L, Ong S, Talor MV, Barin JG, Baldeviano GC, Kass DA, Bedja D, Zhang H, Sheikh A, Margolick JB, Iwakura Y, Rose NR, Cihakova D: Cardiac fibroblasts mediate IL-17A-driven inflammatory dilated cardiomyopathy. J Exp Med 2014, 211:1449-1464 
62. Groom JR, Luster AD: CXCR3 ligands: redundant, collaborative and antagonistic functions. Immunol Cell Biol 2011, 89:207-215

63. Farber JM: Mig and IP-10: CXC chemokines that target lymphocytes. J Leukoc Biol 1997, 61:246-257

64. Martin FJ, Parker D, Harfenist BS, Soong G, Prince A: Participation of $\mathrm{CD} 11 \mathrm{c}(+)$ leukocytes in methicillin-resistant Staphylococcus aureus clearance from the lung. Infect Immun 2011, 79:1898-1904

65. Qin S, Rottman JB, Myers P, Kassam N, Weinblatt M, Loetscher M, Koch AE, Moser B, Mackay CR: The chemokine receptors CXCR3 and CCR5 mark subsets of $\mathrm{T}$ cells associated with certain inflammatory reactions. J Clin Invest 1998, 101:746-754

66. Sallusto F, Lenig D, Mackay CR, Lanzavecchia A: Flexible programs of chemokine receptor expression on human polarized T helper 1 and 2 lymphocytes. J Exp Med 1998, 187:875-883

67. Holland SM, DeLeo FR, Elloumi HZ, Hsu AP, Uzel G, Brodsky N, Freeman AF, Demidowich A, Davis J, Turner ML, Anderson VL, Darnell DN, Welch PA, Kuhns DB, Frucht DM, Malech HL, Gallin JI, Kobayashi SD, Whitney AR, Voyich JM, Musser JM, Woellner C, Schaffer AA, Puck JM, Grimbacher B: STAT3 mutations in the hyperIgE syndrome. N Engl J Med 2007, 357:1608-1619

68. Minegishi Y, Saito M, Tsuchiya S, Tsuge I, Takada H, Hara T, Kawamura N, Ariga T, Pasic S, Stojkovic O, Metin A, Karasuyama H: Dominant-negative mutations in the DNA-binding domain of STAT3 cause hyper-IgE syndrome. Nature 2007, 448: $1058-1062$
69. Puel A, Cypowyj S, Marodi L, Abel L, Picard C, Casanova JL: Inborn errors of human IL-17 immunity underlie chronic mucocutaneous candidiasis. Curr Opin Allergy Clin Immunol 2012, 12 : 616-622

70. Paulson ML, Freeman AF, Holland SM: Hyper IgE syndrome: an update on clinical aspects and the role of signal transducer and activator of transcription 3. Curr Opin Allergy Clin Immunol 2008, 8: $527-533$

71. Ito R, Mori M, Katakura S, Kobayashi N, Naruto T, Osamura Y, Aihara Y, Yokota S: Selective insufficiency of IFN-gamma secretion in patients with hyper-IgE syndrome. Allergy 2003, 58: 329-336

72. Paganelli R, Scala E, Capobianchi MR, Fanales-Belasio E, D'Offizi G, Fiorilli M, Aiuti F: Selective deficiency of interferongamma production in the hyper-IgE syndrome. Relationship to in vitro IgE synthesis. Clin Exp Immunol 1991, 84:28-33

73. Del Prete G, Tiri A, Maggi E, De Carli M, Macchia D, Parronchi P, Rossi ME, Pietrogrande MC, Ricci M, Romagnani S: Defective in vitro production of gamma-interferon and tumor necrosis factor-alpha by circulating $\mathrm{T}$ cells from patients with the hyper-immunoglobulin E syndrome. J Clin Invest 1989, 84: $1830-1835$

74. Thammavongsa V, Missiakas DM, Schneewind O: Staphylococcus aureus degrades neutrophil extracellular traps to promote immune cell death. Science 2013, 342:863-866 